\title{
Gains and Losses in Ecosystem Services: Trade-off and Efficiency Perspectives
}

\author{
Trung Thanh Nguyen
}

\section{Habilitation Thesis}

University of Bayreuth

\section{Citation information:}

Trung Thanh Nguyen, 2015. Gains and Losses in Ecosystem Services: Trade-off and Efficiency Perspectives. Habilitation Thesis. University of Bayreuth, Bayreuth. 


\title{
Gains and Losses in Ecosystem Services: Trade-off and Efficiency Perspectives
}

\author{
Habilitation Thesis for the Venia legendi in Ecosystem Services
}

\author{
Trung Thanh Nguyen
}

Professorship of Ecological Services

Faculty of Biology, Chemistry and Geosciences

University of Bayreuth

Universitätstr. 30

95440 Bayreuth
Institute for Environmental Economics and World Trade

Faculty of Economics and Management

Leibniz University of Hannover

Königsworther Platz 1

30167 Hannover

Accepted: 04.11.2015 


\section{Introduction}

\section{Problem statement and research motivation}

Humans rely on nature for various benefits to enhance their well-being (Pearce and Moran, 1994; Daily, 1997; Hooper et al., 2005; MA, 2005; Lehmann et al., 2009). These benefits were termed as nature's services (Westman, 1977) which are now commonly referred to as ecosystem services (ES) (Fisher et al., 2009). The contribution of ES to human well-being is widely documented, ranging from provisioning services to regulating, supporting, and cultural services (de Groot, 1987; Costanza et al., 1997; MA, 2005; TEEB, 2010). However, the gains in human well-being and economic development derived from nature have been achieved at the losses in many ES as the consequences of human actions taken to increase the supply of only a certain number of ES (Foley et al., 2005; Bennett et al., 2009). During the recent decades, anthropogenic impacts on ecosystems have increased to an alarming level (MA, 2003; Halpern et al., 2008). Over the past 50 years, humans have changed ecosystems more rapidly and extensively than in any comparable period of time in human history (MA, 2005; Rodrigues et al., 2006; Koellner and Geyer, 2013). For example, agriculture has been intensified with chemical fertilizer overuse to increase food supply. This has contributed to a deterioration of water systems in many parts of the world (Tilman et al., 2002; Nguyen et al., 2014a). In addition, ES are often neglected in management and planning (de Groot, 2006). In many cases, the combined effect of inadequate management and altered natural regimes has degraded the capacity of ecosystems to supply ES (Folke et al., 2004; Petz et al., 2012). Moreover, climate change due to increasing atmospheric carbon dioxide concentration is altering the radiation input, temperature and precipitation regimes of ecosystems, and thus, shifts both water balances and production (Kabat et al., 2004; Canadell et al., 2007). Atmospheric deposition (Schulze, 1989) and intensive land use (Vitousek et al., 1997; Würtenberger et al., 2006; Vignola et al., 2010; de Baan et al., 2013) have modified plant growth, nutritional balances of ecosystems, nutrient losses to aquatic systems, susceptibility of organisms to disease, composition of communities, and ecosystem resistance to stresses. These modifications in ecosystem functions affect derived ES (de Groot et al., 2010; Egoh et al., 2012; Ayanu et al., 2015). These problems, unless addressed, will substantially diminish the benefits that future generations obtain from ecosystems and are a barrier to achieving further development (MA, 2005; Baumgärtner and Quaas, 2010a).

One of the key challenges of ES science is determining how to manage multiple ES in an efficient, equitable, and sustainable manner. Attempts to enhance a single ES often lead to gains 


\section{Introduction}

(synergies) or losses (trade-offs) in other ES (Elmqvist et al., 2011), as ES are not independent of each other (Pereira et al., 2005), and the relationship between them may be highly nonlinear (van Jaarsveld et al., 2005). Individual ES can be thought of as different elements of an interrelated whole or bundle (Cumming and Peterson, 2005) and is under different direct and indirect drivers of changes (MA, 2005; Tenhunen et al., 2015). The general increase in provisioning services over the past century has been achieved at the expense of decreases in regulating and cultural services, and biodiversity (Bennett and Balvanera, 2007; Carpenter et al., 2012). For example in agriculture, a typical trade-off is between provisioning services such as food, fibre or bioenergy and regulating services such as water purification, soil conservation, or carbon sequestration (MA, 2005; Nguyen and Tenhunen, 2013). In some cases, a trade-off may be an explicit choice; but in others, trade-offs arise without premeditation or even awareness that they are taking place (Rodriguez et al., 2006). Therefore, trade-offs in ES should be managed to either reduce their associated costs to society or enhance ecosystem functionality and net human well-being (Raudsepp-Hearne et al., 2010). Identification of trade-offs allows policy makers to better understand the hidden consequences of preferring one ES to another (Haase et al., 2012). However, ES trade-offs are temporally and spatially dependent (Tenhunen et al., 2015) and, thus, examining ES trade-offs at different time and spatial scales would contribute to an improved understanding for a sustainable acquisition of ES. This was the first motivation for the thesis.

Another challenge of ES science is the need to integrate different academic disciplines and research approaches to provide more robust information for decision making. ES science includes at least ecology (ecosystems) and economics (services) (Koellner, 2010). The notion of ES in general and of ES trade-offs in particular has deserved much scientific attention (see Fisher et al., 2009; Abson et al., 2014) as a way to communicate societal dependence on ecological life support systems (Gómez-Baggethun et al., 2010). Progress in this fast-moving field is also revealing the fact that there are still challenges to assess and manage ES in relations to changes in human well-being; and many of these challenges might not be able to be solved with conventionally disciplinary research approaches. This is because the ecological underpinning of economic studies is often limited (Brookshire et al., 2007); and ecological models often lack appropriate economic considerations (Brouwer and Hofkes, 2008). This disciplinary focus, thus, limits our ability to draw general conclusions and derive policy implications. New research is needed that considers the full ensemble of processes and feedbacks, for a range of biophysical and socio-economic factors, to better understand and manage the dynamics of the relationship between humans and the ecosystems on which they rely (Carpenter et al., 2012). Therefore, integrating economics and ecological sciences to provide useful information for policy making (Pagiola and Platais, 2007; Engel et al., 2008) is a key step required for global conservation and sustainability (MA, 2005; Wei et al., 2009). This consideration has led to an increasing demand for interdisciplinary research approach in ES studies (Costanza et al., 1993; Holling, 


\section{Introduction}

2001; Brouwer and van Ek, 2004; Wätzold et al., 2006; Drechsler and Wätzold, 2007; Häyhä and Franzese, 2014; La Notte et al., 2015). This was the second motivation for the thesis.

At the same time, work at the interface of ecology and economics has inspired a major transformation in the way people think about the environment (Turner and Daily, 2008). Increasingly, ecosystems are seen as capital assets, with the potential to generate a stream of ES of vital importance to human well-being (de Groot et al., 2010). In this regard, ES are considered as a return on natural capital, e.g., the return for investing in building or conserving this natural capital (Heal, 2007). This leads to the questions of sustainability (WCED, 1987; Norton and Toman, 1997; Hartwick, 2000; Howarth, 2007; Baumgärtner and Quaas, 2010b) and efficiency (Neumayer, 2003; Coelli et al., 2007; Baumgärtner and Quaas, 2009; Hein, 2010) in ES science. In fact, efficiency and sustainability are among the basic notions in economics. Although ES are becoming a popular topic of inquiry, few studies have applied such basic economic notions to ES studies (Farley et al., 2012). Whereas sustainability economics has been conceptualized and developed (Baumgärtner and Quaas, 2010a, b), economic efficiency studies in ES has received much less attention. This was the third motivation for the thesis. To my understanding, application of the economic efficiency notion to examining ES trade-offs is considered supplement to the conventional ES trade-off analysis approach, as it contributes to the identification of opportunity costs of preferring a specific resource (e.g., land) use option, thus, indicates different alternatives of ecosystem use and management for decision makers.

The last motivation for the thesis was on the implications of these interdisciplinary and efficiency ES trade-off studies. From an economic perspective, ES can be considered positive externalities; but many ES are of public goods character and have no market prices. Policy instruments are, thus, required to internalize these positive externalities (Coase, 1960; Costanza et al., 1997; Drechsler and Wätzold, 2009; García-Amado et al., 2011). Those instruments include payments for ES (PES). However, most of the current PES systems are input-based, meaning that they compensate landowners for "inputs" such as trees planted, rather than for true "outputs" of ES such as, for example, increased water regulation capacity. This is because such outputs are difficult and expensive to assess and quantify (Engel et al., 2008; Nguyen et al., 2013). The input based approach of PES might not be consistent with the requirement that PES should be contingent on the actual provision of ES (Wunder et al., 2005), indicating the need to develop an output-based approach of PES. In addition, sustainable acquisition of ES and successful implementation of PES programs must be under a good governance system, especially effective institutions (Scarlett and Boyd, 2013) that requires transparency, fairness, accountability, and effectiveness (NRC, 2013). One of the most important institutional factors which are relevant for ES and PES is a clearly defined and effectively enforced property right system (Lambini and Nguyen, 2014). Thus, such a system must be considered in ES studies.

With these motivations and the aim at contributing to an improved understanding of ES science, this habilitation thesis was organized into three closely related sections: (i) trade-offs and 


\section{Introduction}

drivers of changes in ES (Part A), (ii) efficiency and improvement of ES (Part B), and (iii) policy and research implications for ES (Part C). In Part A, classical trade-offs in ES were investigated at field, sub-landscape, and regional levels. In Part B, the notion of economic efficiency was used to implicitly determine economic-environmental trade-offs, which are relevant to ES science. In Part C, an output-based PES and an effective institutional property right system for ecosystem management were discussed. Then the integration of ecological studies with economic analyses for a decision making support system was suggested. Finally, a general framework for evaluating trade-offs in ES at a regional level was synthesized, providing implications for further research in this field. Therefore, the thesis contributes to the current literature in several ways: (i) conventional trade-offs between regulating and provisioning services are examined both theoretically and empirically in much more details, with the combination of ecological models and economic analyses, and at different spatial levels; (ii) provisioning and regulating services are quantified in physical and monetary terms which are more convenient and useful for land users and policy makers; (iii) synergies and trade-offs in ES can be identified using the economic efficiency notion; and (iv) payments for ecosystem services are determined with an output-based instead of a traditionally common input-based approach and non-market valuation methods, and effective property right systems for ecosystem management are discussed.

The next sections of the introduction section to this thesis include (i) a theoretical section which reviews the concepts of ES, scarcity and trade-off, and efficiency that leads to the overall research design; and (ii) a summary of the research contributions which fill in the research gaps identified from a detailed review of the current literature. After the introduction section, the papers for the thesis are organized in three sections described above. Finally, a short outlook for future research is presented. Other relevant information is provided in the annex section at the end of this thesis.

\section{Theoretical considerations}

\section{$2.1 \quad$ Understanding ES}

The concept of ES represents a new view on the relationship between humans and nature (Alcamo et al., 2005). It is now commonly accepted that people and institutions appreciate natural systems as vital assets, recognize the central roles these assets play in supporting human well-being, and routinely incorporate their material and intangible values into decision making (Daily et al., 2009; Fisher and Brown, 2014). However, it has been difficult to reach a widely accepted definition of ES, partly due to the disciplinary separation where ES are viewed from different perspectives. Clearly defining and organizing the concept of ES is not just a semantic decision, but it is integral to operationalizing something that can clearly illuminate trade-offs in natural resource management (Wallace, 2007; Johst et al., 2011; Kirchner et al., 2015). The 


\section{Introduction}

debate mainly involves the distinction between ecosystem functions and services, and how to classify the services in order to make them consistently quantifiable (Boyd and Banzhaf, 2007; Ninan and Inoue, 2013).

Along the history of conceptualization, ES are defined as the conditions and processes as well as the actual life support functions (Daily, 1997), or as the goods and services derived from the functions and utilized by humanity (Costanza et al., 1997), or as the goods and services generated by ecosystem functions which in turn are underpinned by biophysical structures and processes. Ecosystem functions are thus intermediate between ecosystem processes and services and can be defined as the capacity of ecosystems to provide goods and services that satisfy human needs, directly or indirectly (de Groot et al., 2010; Stapleton et al., 2014). The Millennium Ecosystem Assessment (MA, 2005) defines ES as functions of ecosystems with values for human well-being and categorizes ES into different groups, namely, provisioning, regulating, supporting, and cultural services. Even though this definition has been criticized for mixing processes for achieving services with services themselves (Wallace, 2007; Olschewski and Klein, 2011), it provides an operational framework to link the functioning of ecosystems to human welfare (Fisher et al., 2009), supports the development of policies and instruments that integrate social, ecological, and economic perspectives (Volk, 2013), and promote new funding sources for biological and environmental conservation (Tallis and Kareiva, 2005).

Nevertheless, the following commonly accepted attributes of ES are relevant for ecosystem management: (i) ecosystems provide not only a single ES but a bundle of different ES. In this regard, the conventional product of agriculture or forestry (e.g., food or timber) is only one part of ES. This understanding can basically change ecosystem management decision making since our demand now includes a set of various ES rather than a single one (Lehmann et al., 2009); (ii) ES are not independent of each other (Pereira et al., 2005), and the relationship between them may be highly nonlinear (van Jaarsveld et al., 2005). Individual ES can be thought of as different elements of an interrelated whole or bundle (Cumming and Peterson, 2005). This requires a careful consideration when making land use decisions since trade-offs and synergies between and among ES may exist. This is because interactions among ES are complicated and often uncertain because different drivers of change may have different levels of impact on individual ES. There are also interactions among the ES themselves, causing changes to alter the provision of another (Bennett et al., 2009); and (iii) many ES are non-marketed and have a "public-good" character, which implies non-rivality and non-excludability, especially those from regulation services (Daily et al., 2009; Zander and Garnett, 2011). This leads to underestimation of service value, free-riding, undersupply, and finally, exploitation and environmental damage (TEEB, 2010). The fact that only a few numbers of ES have clearly established monetary values makes the valuation of ES difficult, considering that many decisions about resource use are made by comparing benefits and costs (Gómez-Baggethun et al., 2010). Any ES that do not have market prices are generally not accounted for in the decision calculus. Neither is the fact that 


\section{Introduction}

the benefits of many resource use decisions are usually enjoyed by small, fairly cohesive groups of people or the current generation, while the costs of foregone ES are borne by larger, more dispersed groups or future generations (Krieger, 2001; Wegner and Pascual, 2011; Cardinale et al., 2012; Loos et al., 2014).

This new view on ES posits a connection between an ecological and an economic aspect as it cuts across both ecology (ecosystems) and economy (services) (Koellner, 2010; Olschewski and Klein, 2011). It is well recognized that ES are not generated by ecosystems alone, but by social-ecological systems (Berkes and Folke, 1998; Tuvendal and Elmqvist, 2011) or humanenvironment systems (Scholz and Binder, 2003; Koellner, 2010). In other words, people are integral parts of ecosystems, and that a dynamic interaction exists between them and other parts of ecosystems. The changes in human conditions can drive, both directly and indirectly, changes in ecosystems and thereby cause changes in human well-being. At the same time, social, economic, and cultural factors unrelated to ecosystems alter the human conditions, and many natural forces influence ecosystems (MA, 2005; Klain et al., 2014). The transformation of natural resources into ES is not only governed by natural ecosystem processes, but also strongly by concerns most often addressed today as social science themes, namely environmental perception, knowledge and available technology, existing political framework, existing environmental policies, and economic interests (Turner and Daily, 2008; Jax et al., 2013). The theory of human-environment systems which is rooted in descriptive and normative decision theory reveals that human and environmental systems are coupled systems (Koellner, 2010; Albertiet al., 2011). The theory of social-ecological systems indicates that the society is a subsystem of the ecosystem, which is different to the theory of human-environment systems, where these two are complementary. Nevertheless, these two system theories can be considered supplementary in investigating the concept of ES because by definition ES include the two components which are interacted. However, both social-ecological systems and human-environment systems are complex and possess critical thresholds, multiple drivers of change and reciprocal feedbacks between the two components (Turner and Daily, 2008; Tenhunen et al., 2015). It means that ES studies must be capable of assessing biophysical aspects, service producers and users, and the policy (Brauman et al., 2007). Therefore, all bio-ecological and economic values of ES must be accounted for in ES assessments (de Groot et al., 2002; Hein et al., 2007; Koellner et al., 2010; Singh et al., 2013).

\subsection{Ecosystem service scarcity, trade-off, and efficiency}

The concept of scarcity is well-known in economics (Becker et al., 2005); and in fact economics is considered as a study of how scarce resources can best be used to fulfil human wants and desires (Mankiw, 2012). Whereas the wants or desires of human beings are unlimited, the means or resources available for meeting these wants or desires are not unlimited and thus need to be 


\section{Introduction}

managed in the best possible efficient way. When the word resource is used, one might think of natural resources. However, this term has a much broader meaning and includes a broad array of other items, such as labor and capital. An individual person, a society, a country, or the whole world usually faces constraints and limitations of available resources (Debertin, 2012).

A traditional understanding on the concept of scarcity in economics is usually limited to relative scarcity, which is referred to as the notion of relative scarcity (Baumgärtner et al., 2006). One good or service is said to be scarce if it carries opportunity costs (Debreu, 1959; Eatwell et al., 1987). In order to obtain one additional unit of the good, one must give up something of another good. In this regard, scarcity is defined in a relative way because a good is scarce in relation to other scarce good (Faber et al., 1994; Faber and Manstetten, 1998; Baumgärtner et al., 2006). Another notion of scarcity is absolute scarcity when scarcity concerns a non-substitutable means for the satisfaction of an elementary need and cannot be levied by additional production. This extension of the concept of scarcity allows both economists and ecologists to incorporate the insights of the natural sciences into the study of the relationship between humans and nature (Baumgärtner et al., 2006).

Due to the fact that resources are scarce, a trade-off arises when a decision on resource use is made. To obtain more of one scarce good, an individual or society collectively must give up some amount of another scarce good (Ayanu et al., 2011). In other words, scarcity implies that not all of society's goal can be pursued at the same time; a trade-off is made of one good against others. More colloquially, a trade-off is a situation where if one thing increases, some other thing must decrease. This concept of trade-off is popular not only in economics but also in ecology or biology. In economics a trade-off, then, involves a sacrifice that must be made to obtain a certain product, service or experience, rather than others that could be made or obtained using the same required resources. In biology, for example, a trade-off occurs when a beneficial change in one trait is linked to a detrimental change in another trait (Keen, 2014).

Taking these concepts into consideration, it is realized that ES, by definition, are also scarce resources and are even becoming scarcer. In some cases, a trade-off may be an explicit choice; but in others, trade-offs arise without premeditation or even awareness that they are taking place (Rodríguez et al., 2006). This can happen when the interactions among ES are ignored (Ricketts et al., 2004), when our knowledge of how they work is incorrect or incomplete (Walker et al., 2002; Kragt and Robertson, 2014), or when the ES involved have no explicit markets (Winthrop, 2014). But even when a decision is the result of an explicit, informed choice, the decision may have negative implications (Rodríguez et al., 2006). As human societies continue to transform ecosystems to obtain greater provision of specific services, we will undoubtedly diminish some to increase others (Foley et al., 2005).

Since our management actions can impact more than one ES and the knowledge of ES interactions is far incomplete, different spatial and temporal scales should be considered in ES studies 


\section{Introduction}

to provide useful information for ecosystem management decision making. ES trade-offs can happen at field plot level where the land user clears woody vegetation and replaces it with crops (Ayanu et al., 2011), at watershed level when upstream farmers intensify their crop production with an excessive use of chemical fertilizers, leading to the deterioration of the water quality for downstream communities (Nguyen et al., 2014a), or even at regional or international level where deforestation and crop intensification in the south have effects on global climate change (Koellner et al., 2010; Rosenzweig et al., 2014). Similarly, management decisions often focus on the immediate provision of an ES, at the expense of this same ES or other services in the future (Rodríguez et al., 2006). A typical example of ES trade-offs in ES is between provisioning and regulating ES, where the gain in a provisioning service (e.g., food or fiber) is associated with the loss in a regulating service (e.g., water regulation).

Given the scarcity of and trade-offs in ES, efficient use and sustainable acquisition of ES become apparent issues. In the most basic form, efficiency means that the society is getting the most it can from its scarce resources. Due to the advances of economics, efficiency is, in the current literature, can be understood from two notions, the narrow and the wide ones with different implications for policy making. The difference is similar to the one between two branches of economics, namely positive and normative economics. The former is rather descriptive, exploring how the world is, while the latter is prescriptive, judging how the world ought to be. A key difference between positive and normative economics is how their validity is judged. Deciding what is good or bad is not merely a matter of science. It also involves our view on ethics, religion, and political philosophy (Baumgärtner and Quaas, 2010a; Mankiw, 2012).

The wide notion of economic efficiency originates from the welfare economics where satisfaction of the needs and wants of individuals is considered as the normative goal. In this sense, efficiency means non-wastefulness in the use of scarce resources to achieve this goal (Baumgärtner and Quaas, 2010b). There are two points which require attention: (i) scarce resources can be used in alternative ways (Robins, 1932). It means that using them in a particular way carries opportunity costs, and (ii) there might be substitutes and complements for particular scarce resources. It means that we need to explore to what extent those substitutes and complements are possible and impact economic behavior with regard to the use of the scarce resources. As there may be trade-offs and opportunity costs, efficiency means that no scarce resources should be wasted in these respects.

Operationally, different criteria have been identified along the history of economic thoughts for the ultimate goal of satisfaction of individual human wants and needs. One of these criteria is Pareto's efficiency which is defined as the economic situation when the circumstances of one individual cannot be made better without making the situation worse for another individual. Pareto's efficiency takes place when the resources are most optimally used. It is the final optimum solution beyond which any change would directly lead to loss in the allocation of resources. Pareto's efficiency is, thus, the complete solution in itself. An allocation is either 


\section{Introduction}

Pareto efficient or it is not. The operationalization of those criteria from a policy perspective is, therefore, based on a social welfare function where the gains and losses in welfare of all individuals are considered. A policy that makes a net gain in welfare is a Pareto's improvement. It is noted that there is no connection between Pareto's efficiency and equity. Therefore, a Pareto efficient outcome may be very inequitable. Considering the ethical issues of equity (fair distribution over individuals at the same time) and sustainability (fair distribution over generations over time), such an outcome is a source of disputes and debates, leading to discussion on trade-offs between efficiency and equity/sustainability. In other words, policy implications from the wide notion of efficiency are valid as this notion is rooted from the ultimate goal of satisfaction of individual wants and needs; yet they are also sources of debates as this notion is from the normative view. Similar to the notion of sustainability, the notion of efficiency also comprises temporal aspects, resulting in the maximization of utility over time. This is usually achieved by discounting, which means giving less weight or importance to events that occur in the future (Olschewski and Klein, 2011). Discounting is justified (i) by considering a positive time preference of the present generation regarding future utility, or (ii) by expecting future generations to be wealthier than the present one (Neumayer, 2007).

The narrow notion of efficiency is also rooted in the non-wastefulness of scarce resources but concerns mainly with the transformation of inputs into outputs of production. In this regard, efficiency is defined technically as the maximum attained output level from a given input level, or as a certain output level from the minimum input level. In other words, a producer is supposed to be inefficient if he/she is still able either to increase the level of outputs from a given level of inputs or to decrease the level of inputs for a given level of outputs. The inclusion of input and output prices leads to another efficiency measure, namely allocative efficiency where the producer chooses the cheapest combination of inputs (cost) or the highest revenue of outputs. The combination of these two efficiency measures creates an overall efficiency measure, the economic efficiency. This is similar in case of consumption. That is, the maximization of utility derived from a certain level of goods/services consumed or the minimization of goods/services consumed for a certain level of utility. As described, such efficiency measures deal solely with "facts" and thus are of the positive perspective. They are mainly undisputable as they are descriptive. However, the main limitation of this notion is, as it is not based on the ultimate goal of satisfying human wants and needs, their implications for policy making are, therefore, narrow.

Due to the facts such as (i) ecosystems have external effects, and (ii) many ES are public goods, policy interventions are required to overcome such market failures. Such interventions include, for example, environmental taxes (Baumol and Oates, 1993; Pagiola and Platais, 2007), command and control regulations, or integrated conservation and development programs (Kiss, 2004). Obviously, such interventions are aimed at increasing the efficiency and sustainability of ES provision, even though the levels of success are apparently different. Since ES are scarce, 


\section{Introduction}

their trade-off analysis plays an important role in determining which ES are preferred at each spatial and temporal scale. Among those policy instruments, payments for ES (PES) have been promoted as a policy mix (Landell-Mills and Porras, 2002; Pagiola et al., 2005; Engel et al., 2008; Drechsler et al., 2010) to increase ES provision. PES systems must be both voluntary and contingent on the actual provision of ecosystem services (Wunder, 2005; Pagiola, 2008). In order for PES to be implemented, ES must be identified and evaluated, and payment mechanisms must be established to encourage the provision of these services (Elmqvist et al., 2010). Payments are normally given to the land user who implements or maintains desired land uses, which are thought to provide the ecosystem services of interest (Nguyen et al., 2013). In principle, PES should be higher than the forgone benefits of the land user (Figure 1). PES thus seeks to internalize what would otherwise be an externality (Pagiola and Platais, 2007).

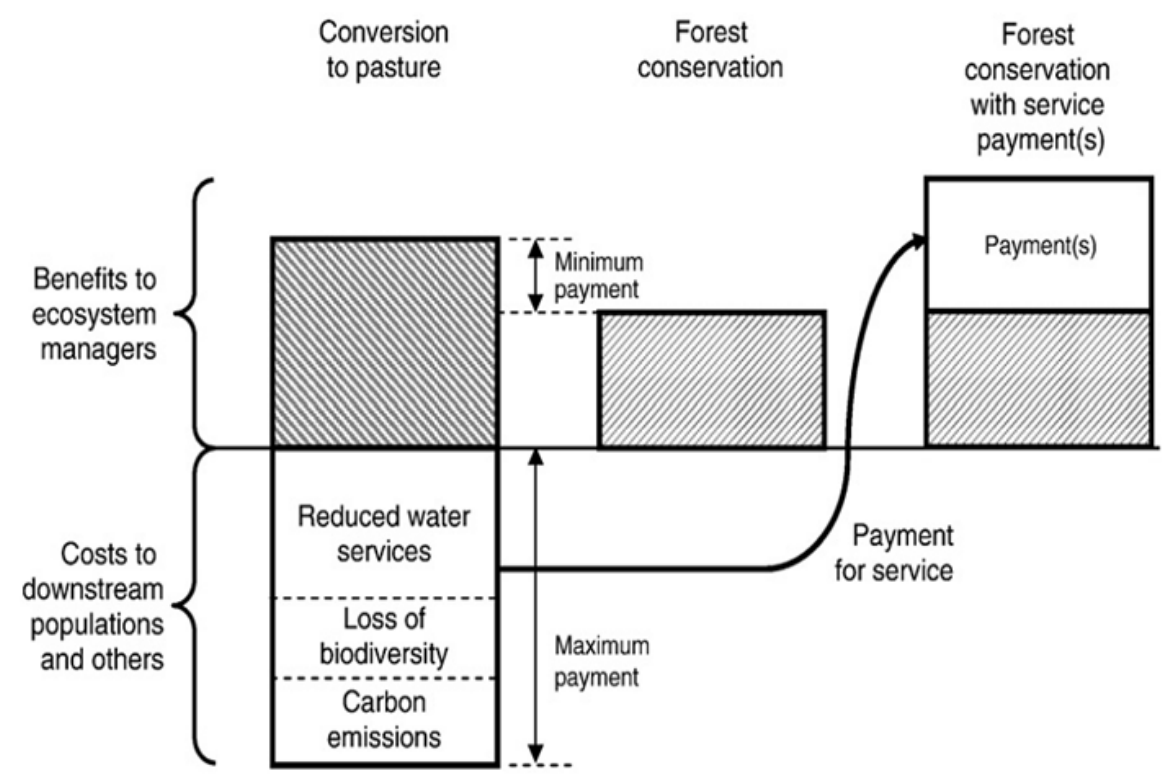

Figure 1: Logic of payments for ES (PES) (source: Pagiola and Platais, 2007)

In addition, even if we are able to identify a PES system, the institutional system (Ostrom, 1990; Hagedorn, 2008) on which the PES system is operating must be supportive. At least it must be transparent, fair, accountable, and effective. This might be often the case in the developed world, but yet popular in developing countries. An effective and robust institutional property right system, for example, is increasingly becoming an important part on the allocation of scarce resources (Demsetz, 1967; Ostrom, 2005; Delacote, 2012). Some institutional property rights have failed to work effectively in developing countries (Humphreys, 2011). Thus, there are several institutional problems concerning the provision of ES in developing countries (Bose et al., 2012). Therefore, the examination of whether the existing institutional systems are in fact useful in enhancing the provision of ES and at the same time promoting economic development is needed (Dimitrov, 2005; Lambini and Nguyen, 2014). 


\section{Introduction}

\subsection{Research design}

These above concepts are the backbone of this thesis in which the main concerns are on the gains and losses in ES in relation to human impacts. The starting point of the consideration on the research design is with a production process that humans undertake to earn their livelihoods (Chambers and Conway, 1992; Turton, 2000; Carney, 2002; Brown et al., 2006; Nielsen et al., 2013), for example, agricultural production or forest activities. These sectors are considered because they are directly related to nature (Debertin, 2012). This production process transforms inputs (e.g., land and fertilizers) into outputs. Outputs can include both wanted (e.g., grain) and unwanted ones (e.g., nutrient surplus due to overuse of manure and/or chemical fertilizers). This is referred to as joint production (Baumgärtner et al., 2001) that follows the laws of thermodynamics, including the material balance principle (Coelli et al, 2007; Nguyen et al., 2012). From an ecological point of view, this production process can be modelled using ecologically process-based models (Nguyen and Tenhunen, 2013; Ruidisch et al., 2014) in which all factors that have a direct influence on the production process can be included, for example, soil fertility and climatic variations. In this way it is of course possible to examine the effects of these direct factors on the production process (Tenhunen et al., 2015).

From an economic point of view, the concept of economic efficiency (the narrow notion as discussed above to avoid normative disputes) can be applied to examine the input-to-output transformation process. As some outputs are not desirable, they might have (negative) external effects to other parties that are not involved in the production or consumption of the wanted outputs. There are of course by-products that have positive external effects. These effects are termed in economics as externalities which bring costs (negative) or benefits (positive) to both individuals and the society. For example, agricultural intensification in an upstream region of a watershed brings negative effects to downstream communities. Such negative effects lead to local (private) short-term and regional (social) long-term environmental costs. If the up- and downstream communities cannot negotiate or there are no clearly defined property rights as in

the Coase theorem, then government's interventions are required. Such interventions can be, for example, a command and control regulation with regard to fertilizer use, an environmental tax (Engel et al., 2008), pollution tradable permits (Wissel and Wätzold, 2010), or a policy mix such as PES requiring either the downstream community to pay their upstream partners not to pollute or vice versa. As described, these interventions aim to internalize the external effects and have indirect interventions on the production process. If the downstream community has to pay, then the flows of ES and their payments can be seen. Those policy interventions are, in fact, enhance the efficiency of the production from a social point of view.

These considerations led to the overall research design of this thesis (Figure 2), which indicates the relationship among different stakeholders (e.g., producers, consumers, and society as a whole). It is noted that the producers (of the provisioning services) and ES providers can be 


\section{Introduction}

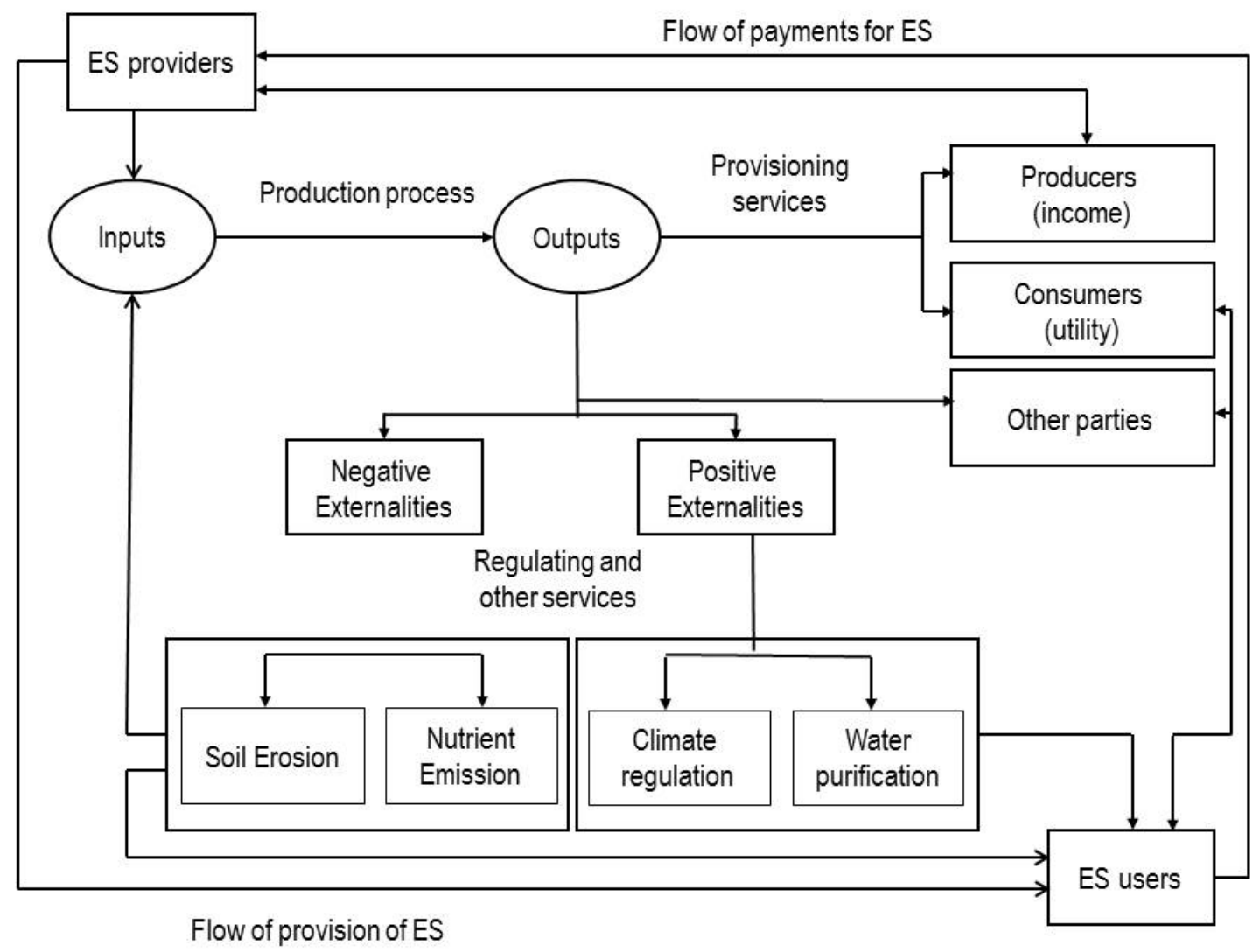

Figure 2: Overall research framework

the same. It means that during their production process, they not only produce the provisioning services but also (probably) provide other ES. Similarly, consumers of the provisioning services and other parties which are not directly involved in the production and consumption of the provisioning services are ES users. This simple framework of course cannot capture all issues with regard to gains and losses in ES due to human activities. Nevertheless, it provides a systematic conceptualization of how we can investigate these issues and give a lot of insights on drivers of and interactions among different land use alternatives that lead to ES trade-offs, for example, between provisioning (e.g., food) and regulating services (e.g., water purification).

The framework also indicates the potential of applying the narrow notion of the efficiency concept to investigate ES trade-offs by examining which production process (e.g., a certain land use type or land management practice) can be able to provide more provisioning or regulating services, ceteris paribus, and consequently help identify the trade-offs between these services. For example, given the same level of input use (e.g., land and chemical fertilizers), a specific land use type is preferred if it provides more food (provisioning service) but less chemical pollutants which negatively affects the water purifying capacity of the ecosystem (regulation service). In this regards, even though there are differences between the conventional ES trade-off analysis and efficiency application (Table 1), the latter is considered complementary to the former. In ad- 


\section{Introduction}

Table 1: Comparison between conventional trade-off and efficiency perspectives

\begin{tabular}{|c|c|c|}
\hline & $\begin{array}{l}\text { Conventional trade-off perspec- } \\
\text { tive }\end{array}$ & Efficiency perspective \\
\hline Goal & To identify gains and losses & To evaluate performance \\
\hline $\begin{array}{l}\text { Research } \\
\text { question }\end{array}$ & $\begin{array}{l}\text { How much? (e.g., how much would } \\
\text { farm income and soil erosion change } \\
\text { if this forested parcel is converted to } \\
\text { annual crop cultivation?) }\end{array}$ & $\begin{array}{l}\text { How? (e.g., how is the economic } \\
\text { performance of farmers, sectors, or } \\
\text { the nation as a whole?) }\end{array}$ \\
\hline Example & $\begin{array}{l}\text { Tradeoff between farm income and } \\
\text { leached nitrate }\end{array}$ & Economic efficiency of rice farms \\
\hline Relevance & Different actors & Different decision making units \\
\hline Requirement & More than one ES involved & $\begin{array}{l}\text { At least one input and output (and } \\
\text { prices) }\end{array}$ \\
\hline Result & ES trade-offs are described & Efficiency measures are identified \\
\hline
\end{tabular}

dition, efficiency applications can identify the opportunity cost of preferring (private) economic consideration to (socially) environmental considerations or vice versa. The main difference is, whereas a conventional trade-off analysis is a direct exercise, an efficiency application includes a procedure of at least two-steps. In each step, the efficiency evaluation is undertaken with regard to a specific consideration, for example, first in terms of provisioning service (farm income), and then in terms of regulating services (water purification). The comparison of the efficiency measures in these cases can show potential trade-offs or synergies.

The research presented in this thesis is designed within this framework. First, the conventional trade-offs and drivers of changes in ES are investigated (the upper and left part of the framework). This part is ecological and economic integrated. Then the efficiency notion is applied to implicitly examine the trade-offs between economic and environmental performance of land users (the right and lower part of the framework), which can provide useful information to ecosystem management for ES. In the last part, the implications for ES from both policy and research perspectives are discussed. The policy implications include payments for ES and institutional system analysis. Finally, these above and other aspects relevant for ES science are synthesized in the two last papers. In the next section, the current literature is reviewed to identify the research gaps and describe the contribution of the research within the above framework to fill in the gaps.

\section{Literature review and research contribution}

\subsection{Trade-offs and drivers of changes in ES}

Various scientific efforts have been spent to conceptualize ES within social-ecological or humanenvironment systems (see Koellner et al., 2010 for a review; Carpenter et al., 2012) and ES 


\section{Introduction}

trade-offs (MA, 2005; Johst et al., 2011), from both ecological and economic perspectives, especially after the release of MA in 2005. These include theoretical considerations (Rodríguez et al., 2006; Bennett et al., 2009) and empirical evidence (Tallis et al., 2008; Carreno et al., 2012; Lester et al., 2013), deal with a couple of ES at different scales (Nelson et al., 2009; Ayanu et al., 2011), and cover a specific or multiple sector(s) (Power, 2010; Polasky et al., 2011; White et al., 2012). Such efforts have, thus, clearly contributed to an improved understanding of ES trade-offs. The analytical models and tools have also been reviewed and evaluated (see Seppelt et al., 2011 for a detailed review), indicating a general trend of integrating ecological and economic considerations (Drechsler and Wätzold, 2007), even though there are differences in terms of structure and coverage of ecological and economic models (Drechsler et al., 2007).

For example, at landscape level, Rodríguez et al., (2006) classify ES trade-offs along three axes: spatial scale, temporal scale, and reversibility. Spatial scale refers to whether the effects of the trade-off are felt locally or at a distant location. Temporal scale refers to whether the effects take place relatively rapidly or slowly. Reversibility expresses the likelihood that the perturbed ES may return to its original state if the perturbation ceases. They also indicate that trade-off decisions show a preference for provisioning, regulating, or cultural services (in that order); and request that managers should complement their actions with monitoring programs that, in addition to monitoring the short-term provisions of services, also monitor the long-term evolution of slowly changing variables. Policies can then be developed to take into account ES trade-offs at multiple spatial and temporal scales. Successful strategies will recognize the inherent complexities of ecosystem management and will work to develop policies that minimize the effects of ES trade-offs. Empirically, Raudsepp-Hearne et al., (2010) develop a framework for analyzing the provision of multiple ES across landscapes and present an empirical demonstration of ES bundles as sets of services that appear together repeatedly in Quebec, Canada. Their results show landscape-scale trade-offs between provisioning and almost all regulating and cultural services, and that a greater diversity of ES is positively correlated with the provision of regulating services. The landscape level research has been recently promoted with the application of various landscape models such as the Integrated Valuation of Ecosystem Services and Tradeoffs (InVest), the Soil and Water Assessment Tool (SWAT), and many other models (Viglizzo and Frank, 2006; Nelson et al., 2009; Seppelt et al., 2009; Johst et al., 2011; Johnston et al., 2011; Mueller et al., 2014; Polasky et al., 2014; Verutes and Rosenthal, 2014).

At sectoral level, some authors analyze ES trade-offs in agriculture (Mimouni et al., 2000; Power, 2010; Kremen and Miles, 2012; Tancoigne et al., 2014), in livestock sector (Bernués et al., 2011), in forestry (Steffan-Dewenter et al., 2007; Seidl et al., 2007; McKechnie et al., 2011; Wang and $\mathrm{Fu}, 2013$ ), in bioenergy (Bryan et al., 2010), in fishery/marine (Swallow et al., 2009; Lester et at., 2013). Others also determine ES trade-offs between and among sectors. For example, some deal with trade-offs between agriculture and forestry (Illukpitiya and Yanagida, 2010; Paterson and Bryan, 2012), some deal with trade-offs among agriculture, bioenergy, water quality and 


\section{Introduction}

quantity (Lautenbach et al., 2012; Poppenborg and Koellner, 2014). The progress in this field includes the application of increasingly complicated and integrated models taking into account both ecological and economic aspects (Seppeltand Richter, 2005; Kareiva et al., 2007; Haase et al., 2012; Lautenbach et al., 2012). These also include efforts devoted to spatial configuration of landscapes or watersheds for multiple ES (Seppelt and Voinov, 2003; Holzkämper and Seppelt, 2007; Mitsch et al., 2008; Ulbrich et al., 2008; Daily et al., 2009; Ausseil et al., 2012; Herzig et al., 2013; Lautenbachet al., 2013). In addition, many studies try to incorporate economic aspects explicitly into ES trade-off analysis (Steffan-Dewenter et al., 2007; Chisholm, 2010; Polasky et al., 2011; Carreno et al., 2012). The economic background of such studies have also been improved by a number of other studies (Farber et al., 2002; Heal et al., 2005; Fisher et al., 2007; Norgaard, 2010; Gómez-Baggethun et al., 2010; Bateman et al., 2013; Baveye et al., 2013; Kumar et al., 2013).

While these studies provide a lot of insights regarding ES trade-offs, it is certain that our knowledge on possible ES trade-offs is still far incomplete. This is because the sustainable acquisition of ES requires an thorough understanding of the trade-offs in ES and the influences of variables acting at different time and spatial scales, as well as the complex interactions among social and biophysical system components (Carpenter et al., 2012, Galat and Berkley, 2014). The spatial and temporal characteristics are also of course specific, making the generalization of relevant findings difficult. Empirical information on the quantitative relationship between land use and ecosystem management and the provision of ES at the local and regional scale is, therefore, still scarce (ICSU et al, 2008; de Groot et al., 2010), especially at field or sublandscape scale where crop choices, farming techniques, or nutrient management practices are often under the control of a single land user. Thus, the following papers described in Part A (trade-offs and drivers of changes in ES) contribute to filling these research gaps.

In Paper 1, the effects of nutrient best management practices (NBMP) on leached nitrate and farm income in Heaen catchment, South Korea were determined. In this area, intensive highland crop cultivation with a high level of $\mathrm{N}$ and $\mathrm{P}$ surplus has degraded freshwater quality. Soil erosion has also contributed to water quality degradation and lowering the longevity of the Soyang Dam in addition to the feedback effect of reducing crop yield (provisioning service) due to decreasing fertility of soil surface. Such negative effects in complex terrains are more severe and difficult to manage under the monsoon climatic conditions. Obviously, increased soil erosion or leached nitrate from agrochemicals used in agriculture can lead to welfare losses of land users due to decreased soil productive capacity in addition to the increased water pollution abatement cost. This is local private costs (feed-back costs) which might force farmers to change their management practices. For example, they might adopt soil conservation measures or nutrient best management practices (NBMP). Such increased soil erosion or leached nitrate from agrochemicals used in agriculture can lead to social welfare losses as well. Therefore, it is needed to identify which NBMP can reduce both private and social welfare losses. To 


\section{Introduction}

examine economic costs and benefits of various NBMP, farm interviews and plot experiments were undertaken in 2010. Famers were cultivating several crops such as rice, radish, cabbage, beans, and maize, of which radish (Raphanussativus $L$.) is the most important highland cop in terms of cultivated land area. The usual cultivation method for highland crops such as radish is by ridge cultivation with plastic mulch using black impermeable polyethylene (PE) film. The growing season of radish starts in June and ends in August. This is also the time with the highest rain intensity and frequency. Therefore, the adoption of NBMP is particularly important for achieving sustainable agriculture. The synergies and trade-offs between nitrate leaching and net farm income of radish cultivation with different NBMP were examined. The simulations of nitrate leaching were performed using the numerical code HydroGeoSphere (Therrien et al., 2010). The results show that the use of plastic mulch, fertilizer placement only in ridges, split fertilization and combination of these NBMP reduced nitrate that percolates into the groundwater system. The plastic mulching and fertilizer placement only in ridges were also shown to be economically profitable, demonstrating synergies between net farm income and nitrate leaching. However, there are trade-offs in the cases of split fertilization and combination of NBMP as they lower both leached nitrate and net farm income. Thus, there are opportunities for policy makers to motivate farmers to adopt split fertilization and combine NBMP. This can be done by compensating farmers for the losses of their net farm income (Nguyen et al., 2014a).

In Paper 2, the trade-offs between a provisioning service (marketable part of biomass accumulation) and a regulating service (water runoff prevention) were investigated at sub-landscape scale covering different land use types in a developing country context (Vietnam), where traditional slash and burn cultivation method is still existing. For this purpose, the quantification of the provisioning and regulating services using a biophysical simulation model - LUCIA (Marohn, 2009) - was first conducted. These services were then spatially and temporally stimulated with different land use scenarios. The temporal dimension includes both annually and over a planning period of 20 years. Of course the planning period can be different; the selection of 20 years was due to the fact that the agricultural land in Vietnam was granted to land users for a maximum of 20 years (Nguyen, 2008; Nguyen et al., 2010; Nguyen et al., 2012). In addition, this time period would be sufficient for rubber or forest trees considered to reach a marketable size. An economic analysis was undertaken to identify all local private costs and benefits of different land use scenarios. Finally, the gains and losses in these ES were compared in order to identify the synergies and trade-offs. The results show that among the alternative land-use scenarios (business as usual, maize monocropping, and rubber plantations) tested in this study, with regard to the provisioning (agricultural commodity production for markets) and water regulation services, rubber plantations appear as a better alternative than maize monocropping. However, the introduction of rubber plantations should consider through investigation of the risks and uncertainties involved in terms of both impact on the environment and benefits to the farmers. The implementation of rubber plantation projects should thus take into account the interests 


\section{Introduction}

of the stakeholders in the area. Since the traditional composite swidden agriculture (CSA) cannot continue due to the increasing population and economic growth, further investigation of other promising land-use alternatives is necessary to ensure sustainable management of natural resources and supply of ecosystem services. Moreover, research in combining the traditional CSA systems with other land-use options is useful to ensure sustainable land use (Ayanu et al., 2011).

In Paper 3, the effects of an important driver of ecosystem changes - climate variations - on ES, namely biomass accumulation in agricultural crops and forest trees were examined. The context that motivated the study includes both climate change (Stern, 2007; IPCC, 2007; Anthoff et al., 2009; Nordhaus, 2010; Tol, 2010) due to anthropogenic greenhouse emissions, and energy security (IFAD, 2007; IPCC, 2012), along with the environmental damages and losses in ES (IEA, 2008) and indirect land use changes (Lapola et al., 2010; Bowyer, 2010; Plevin et al., 2010) due to maize monoculture for bioenergy production. It is well-known that simulating regional variations in gross primary production (GPP) and yields of major land cover types is complex because of differences in plant physiological properties, landscape topography, and climate gradients. In this study, the inter-annual and inter-regional variation, as well as the effect of summer drought, on gross primary production and crop yields of nine major land uses within the state-funded Bioenergy Region Bayreuth in Germany were analyzed. A simulation framework using a process based model which accounts for variations in both $\mathrm{CO}_{2}$ gas exchange, and in the case of crops, growth processes was developed. The results indicate a severe impact of summer drought on GPP, particularly of forests and grasslands. Yields of winter crops, early planted summer grain crops as well as the perennial $2^{\text {nd }}$ generation biofuel crop Silphium perfoliatum, on the other hand, are buffered despite drought by comparatively mild winter and spring temperatures, suggesting a comparative advantage for these crops in the cooler and upland part of the region. In contrast, grasslands and annual summer crops such as maize and potato do not exhibit any apparent regional pattern in the simulations. The $2 n d$ generation bioenergy crop exhibits significantly higher GPP and yields compared to the conventional bioenergy crop maize, suggesting that cultivation of $S$. perfoliatum should be increased for economic and environmental reasons (Ruidisch et al., 2014).

In Paper 4, the conservation potential of different farming techniques at field plot level in a watershed region in South Korea was compared. It is well-known that the cultivation of row crops on mountainous farmland can generate severe soil erosion due to low ground cover, especially in the early growth stages. Organic farming, due to the absence of herbicides, can support the development of weeds and increase the ground cover compared to conventional farming. However, the benefits towards soil erosion, and the conservation potential of organic farming systems, in terms of herbicide application and weed growth, have not been investigated. The aim of the study was to identify how conventional and organic farming influence the erosion rate of soil, due to row crops cultivated on mountainous farmland in the presence or absence of 


\section{Introduction}

agricultural chemicals. Multiple vegetation parameters of crops and weeds of conventional and organic farms cultivated with bean, potato, radish, and cabbage in a mountainous watershed in South Korea were measured. The long-term soil erosion rates were stimulated with the Revised Universal Soil Loss Equation (RUSLE) by using 13 years of recorded rainfall data in order to account for the temporal variability of monsoonal rainfall. The average annual erosion rates for the study area were determined to be between 30.6 tons $\mathrm{ha}^{-1} \mathrm{yr}^{-1}$ and 54.8 tons $\mathrm{ha}^{-1}$ $\mathrm{yr}^{-1}$, with maximum values when radish was grown, due to the shorter growing period, higher soil disturbance at harvest, and low amounts of crop residue. Organic farming reduces soil loss for radish by $18 \%$ as a result of a high weed biomass density and cover at the end of the growing season. For potato, organic farming increases soil loss by $25 \%$ due to a reduced crop coverage, which is suspected to have been a consequence of crop-weed competition or increased herbivory associated with the absence of agricultural chemicals. The results demonstrate that organic farming can potentially decrease the soil erosion risk for row crops because it supports weed development in the furrows, but it can also produce higher erosion rates when crop yields are reduced as a consequence, outweighing the protective effect of the weeds. However, the simulated erosion rates under both farming systems exceeded by far any tolerable soil loss. The study concludes that organic farming alone cannot be used to effectively control erosion, and that both farming systems require additional conservation measures, such as winter cover crops and residue mulching, to sufficiently prevent soil loss for row crop cultivation (Arnhold et al., 2014).

\subsection{Efficiency and improvement of ES}

During the past few decades, increasing attention has been paid to environmental externalities (e.g., pollution) caused by economic activities (Coelli et al., 2007; Nguyen et al., 2012). Economists have recognized the need to adjust traditional methods to integrate environmental concerns into standard economic efficiency measures (Hoang and Nguyen, 2013). In other words, the external effects of economic activities must be taken into considerations; and this of course includes the effects on ecosystems and derived ES. Such an environment-adjusted economic efficiency concept is termed as environmental efficiency. Due to such adjustments, there might be trade-offs between environmental and economic efficiency. Analyses of environmental and economic efficiency trade-offs can lead to several important management and policy implications. For example, first, it is possible to calculate how much it costs to adjust a production process from the economic efficient to the environmentally efficient status. This cost could be interpreted as the shadow cost of becoming more environmentally friendly. Second, one can measure how much more harms to the environment if the production process is adjusted to move from the environmentally efficient to the economic efficient status. Such a trade-off analysis provides useful implications for policy making and indicates the opportunity cost of preferring economic efficiency to environmental efficiency or vice versa. It is thus important to 


\section{Introduction}

measure both environmental and economic efficiency as well as their drivers in order to evaluate existing environmental policies and design new policies (Oude Lansink and Wall, 2014). The need to reduce negative environmental impacts of economic activities leads to the idea of more efficient use of resources, including ES. In this regard, efficiency (frontier) analysis (in the narrow sense) has a valuable role to play (Fried et al., 2008, Polasky et al., 2008). Early efforts in this direction include, for example, Tyteca (1999), Färe et al. (1996), Reinhard et al. (2002). Even though such environmnetally oriented efficiency studies do not directly examine trade-offs in ES, their findings are important as they contribute to conserve nature and thus enhance the provision of ES. For example, less nutrient surplus released to water systems can make those systems more healthy. In other words, ES are dealt in an implicit way.

There are currently different approaches for measuring environmental efficiency (see Lauwers, 2009; Oude Lansink and Wall, 2014 for detailed reviews). The first approach considers pollutants as either an additional input (Reinhard et al., 2000; Hailu and Veeman, 2001), or an undesirable output variable (Färe et al., 1989). While desirable outputs are assumed to be strongly disposable, bad or undesirable outputs are treated as weakly disposable, implying that their production could only be reduced by reducing desirable outputs or increasing inputs and is, therefore, costly. Several applications of this approach use input and output distance functions and directional distance functions (Reinhard et al., 1999; Shaik et al. 2002; Oude Lansink and Silva, 2003; Asmild and Hougaard, 2006; Piot-Lepetit and Le Moing, 2007; Zhou et al., 2008; and Skevas et al., 2012). The second approach is referred to as the frontier efficiency models where they use the frontier framework to model relationships between economic and ecological outcomes to derive eco-efficiency measures (Callens and Tyteca, 1999; Tyteca, 1999). The ecoefficiency measures relate the economic value of outputs to the environmental pressures involved in production processes (Picazo-Tadeo et al., 2012). Several empirical studies have applied this approach (Kuosmanen and Kortelainen, 2005; Kortelainen, 2008; Picazo-Tadeo et al., 2011). These applications can be seen as the frontier operationalization of the eco-efficiency concept in the analysis of multidimensional sustainability (Lauwers, 2009).

While these two approaches have been widely applied, their theoretical grounds have some limitations. In particular, the applications involving the inclusion of a pollution variable as an input variable or (bad) output variable into a production technology - are inconsistent with the materials balance principle (see proofs in Coelli et al., 2007) which is regulated by the law of mass conservation that the materials in a production system are not lost and that material inputs end up in either stock accumulation or material outputs. Therefore, a new approach has been promoted, which is referred to as the materials balance approach (Van Meensel et al., 2010; Nguyen et al., 2012; Hoang and Nguyen, 2013). This approach recognizes that nutrients not contained in bad outputs go back into the environment as potential pollutants. Thus, nutrient surplus should be minimized to reduce potential environmental impacts. As noted by Oude Lansink and Wall (2014), environmental efficiency analyses incorporating the materials balance 


\section{Introduction}

principle are relatively recent, with the consequence that studies involving its determinants in this framework are scarce. Our work summarized below is considered pioneer of this approach.

In Paper 5, the cost and nutrient use efficiency of farms were determined using the Data Envelopment Analysis (DEA) approach with a dataset of 96 rice farms in Gangwon province of South Korea from 2003-2007. The findings show that improvements in technical efficiency would result in both lower production costs and better environmental performance. It is, however, not costless for farms to move from their current operation to the environmentally efficient operation. On average, this movement would increase production costs by $119 \%$ but benefit the water system through an approximately $69 \%$ reduction in eutrofying power (EP). It is estimated that the average cost of each EP $\mathrm{kg}$ of aggregate nutrient reduction is approximately 1.2 USD. For technically efficient farms, there is a trade-off between cost and environmental efficiency. It is suggested that agri-environmental policies should be (re)designed to improve both cost and environmental performance of rice farms. This is because farmers would normally like to be as economically efficient as possible and the society tries to minimize the negative external costs and thus to be environmentally efficient. This can be done by adjusting fertilizer prices according to their nutrient content, making the iso-cost and iso-nutrient lines similar (Nguyen et al., 2012).

In Paper 6, it is argued that environmental efficiency which is built upon the materials balance (MB) principle is more suitable than other environmental efficiency measures in situations where the law of mass conversation regulates production processes. In addition, the MB-based environmental efficiency method is particularly useful in analyzing possible trade-offs between cost and environmental performance. Identifying determinants of MB-based environmental efficiency can provide useful information to decision makers but there are very few empirical investigations into this issue. The DEA and stochastic frontier analysis techniques were applied to determine variations in MB-based environmental efficiency. The size of land, fertilizer consumption intensity, cost allocative efficiency, and the share of owned land out of total land are found to be correlated with MB-based environmental efficiency. The results confirm the presence of a trade-off between MB-based environmental efficiency and cost allocative efficiency, suggesting that policies could be (re)designed to help farmers to simultaneously achieve cost efficiency and MP-based environmental efficiency (Hoang and Nguyen, 2013).

In Paper 7, the financial return, technical efficiency, and factors determining the intensity and success of reforestation with a native tree species (Canarium album) were investigated in Vietnam, where the area of degraded forests is substantial, currently about 3.1 million ha of which about 1.7 million ha (55\%) were granted to individual farms for reforestation. However, the result of farmers' reforestation efforts is limited. The research was undertaken because tropical forests continue to degrade globally, with negative consequences for environmental sustainability and forest-dependent human communities (Nagendra, 2007). Despite signs of forest recovery in a few countries (Meyfroidt and Lambin, 2011), the rate of tropical deforestation remains 


\section{Introduction}

alarmingly high (FAO, 2010). Furthermore, the area of degraded tropical forests is large and thus reforestation is important to support people and reduce pressures for additional deforestation. Large reforestation programs have been implemented in a number of countries to deal with the challenges of energy shortage, biodiversity loss, and global climate change. However, little attention has been given to the crucial problem of sustaining economic activity of people who participate in such programs (Chazdon, 2008; Frondel et al., 2012) and finding out the determinants of successful reforestation. It is believed that reforestation provides one of the solutions to the current problem of forest loss and its consequences (Angelsen, 2010). The results show that reforestation with $C$. album is less financially profitable than that with an exotic tree species (Acacia mangium) as the alternative land use option. The subsidy from the government is found insufficient to compensate for the income losses of farmers participating in reforestation with this native tree species. Reforestation with $C$. album could be more successful if participating farmers were equipped to be more technically efficient. Finally, the findings show that the security of forest land property rights and the provision of forest extension services are among the determinants of participation in, and the subsequent success of reforestation with C. album (Nguyen et al., 2014b).

\subsection{Policy and research implications for ES}

Over the past few decades, progress has been made in understanding how ecosystems provide services and how service provision translates into economic value (Daily, 1997; MA, 2005; TEEB, 2010). Yet, it has proven difficult to move from general pronouncements about the tremendous benefits that nature provides to people to credible, quantitative estimates of ecosystem service values (Nelson et al., 2009). The value of ES has been estimated in various ways. In general, the framework has three main parts: (i) measuring the provision of ES as in Part A; (ii) determining the monetary value of ES; and (iii) designing policy tools for managing ES (Polasky et al., 2008). While ecologists and other natural scientists have been engaged in enhancing our understanding of how ecosystem services are produced (Power, 2010), determination of the monetary value of ES is difficult and not straightforward. This is because (i) the concept of value is normative, and (ii) many ES are non-marketed goods or services without any prevailing prices. For those services, various approaches, including travel cost method, contingent valuation, or hedonic price approach have been applied (Losey and Vaughan, 2006; Swinton et al., 2007; Mendelsohn and Olmstead, 2009). The overarching goal of measuring and valuing ES is to use that information to shape policies and incentives for better management of ecosystems and natural resources (Nelson et al., 2009) and thus enhance the provision of ES for human well-being.

This sub-section is devoted to the policy and research implications for ES. In terms of policy implications the focus is on payments for ES (PES) and institutions. As discussed in the theoretical section, while economic justification for PES is clear (Coase, 1960; Costanza et al., 


\section{Introduction}

1997; Gómez-Baggethun et al., 2010; Garcis-Amado et al., 2011) the operationalization of PES programs is much more challenging. In theory, monetary value assigned to PES can range from the opportunity costs to landowners to the true value of all ecosystem services provided, minus transaction costs. In practice, most PES systems are "input-based", meaning that they compensate landowners for "inputs" such as trees planted, rather than for true "outputs" of ecosystem services such as, for example, increased water regulation capacity. This is because such outputs are difficult and expensive to assess and quantify (Engel et al., 2008). It is also quite often the case that, rather than evaluate, quantify, and monetarize actual ecosystem services provided, PES systems simply compensate landowners for provision cost (Ohl et al., 2008). In this case, payments can be based on environmental targets and the cost to farmers for providing the desired land use (Pagiola et al., 2002). Obviously, this cost-covering compensation approach has several shortcomings. For example, it restricts the scope to those who bear some costs. Those who bear no costs do not need to be compensated. This is more problematic when service providers who suffer costs look not only for recompense, but also for a "provider surplus" - gains from the transaction that exceed their costs and make them better-off (Wunder, 2007). This requires a more robust approach to identify PES that is contingent on the actual provision of ES as this can provide an incentive for the land user to enhance the provision of ES, for example afforestation instead of crop farming (Nguyen et al., 2010; Nguyen et al., 2014b).

In Paper 8, a framework to calculate the economic value of forest hydrological services was established. The importance and advantage of forests in providing hydrological services are wellknown, and have been extensively documented (Hewlet, 1982; Börkey et al., 2005; Chang, 2006). Forest hydrological services are beneficial for hydroelectric production, where forests contribute to lower soil sedimentation and store water, and thus, maintain the capacity and prolong the longevity of hydroelectric production plants (Rojas and Aylward, 2002; Nguyen et al., 2013). These services must be paid for. However, the basis for identifying the proper level of payments is under much discussion and substantially different from case to case (Kosoy et al., 2007; Wunder et al., 2008), creating difficulties for policy decision-making and practical application. Progress in the assessment of ES has been impeded by the lack of a standardized classification of which services to evaluate and how (Fisher et al., 2009; Boyd and Banzhaf, 2007). This is because it is often difficult to measure the output of ES. Thus, the quantification and valuation of those services must be carried out in order to establish a basis for the required payment. This paper focused on the most important forest hydrological services, namely for hydroelectric production via water storage and release (water provision), and in the prevention of soil loss with subsequent sedimentation of the reservoir (sediment prevention). Lower sedimentation plays an important feedback role in the economic system, since the longevity of the hydroelectric plant is prolonged. The established framework was applied to the HoaBinh Reservoir in the north of Vietnam, since the HoaBinh Hydroelectric Plant and forest owners recently reached an agreement that the plant would pay the forest owners a certain proportion of the increased revenue for forest water 


\section{Introduction}

provision and sediment prevention services. The study is, thus, of practical significance for the implementation of this agreement. By extending the analysis to different land use change and electricity price scenarios, the findings contribute useful information with respect to sustainable land use and formulation of forest management policy. The valuation is based on measurements over a six-year period from 2001 to 2006 in 240 permanent sample plots in different vegetation types distributed throughout the watershed. The findings indicate that the payments for forest hydrological services for electricity production ranges from 26.3 million USD to 85.5 million USD per year; and that the longevity of the hydroelectric plant can be prolonged by about 35-80 years, depending on the state of forest cover in the watershed, the prices of electricity, and the payment arrangements.

In Paper 9, the forest property right system as an important institutional factor for ecosystem management and provision of ES was discussed. The paper employs property rights based framework coupled with some New Institutional Economics (NIE) (Williamson, 1975; Coase, 1998; Ostrom, 2005) debates as a diagnostic framework for understanding forest property rights. This is because property rights, institutions and public choice are key concepts in the allocation and use of natural resources, including ES. A property right is a bundle of entitlements defining and stipulating the owner's rights, privileges and limitations for the use of resources. Effective institutional property rights are increasingly becoming an important part in the allocation of scarce forest resources and to combat the "tragedy of the commons" thesis. The paper outlines conceptual, analytical, and theoretical aspects of forest institutional property rights and an empirical synthesis of main findings from institutional property rights effectiveness in a cross-country comparative context (Vietnam and Ghana). The Sustainable Livelihoods Framework (SLF) provides empirically insights into how "forest institutional property rights" impact on forest communities' livelihoods and management. The analysis provides support for the argument that forest institutional property rights play important role in the livelihoods of forest dependent communities and in forest management, but that can be context specific as showcased in our findings. Finally, the paper makes some recommendations in institutional analysis of forest property rights, such as strong and clearly defined property rights, integration of formal and informal rights and suggests strong linkage between institutional property rights and sustainable livelihoods as a "panacea" for sustainable forest livelihoods and management in developing countries.

In addition to these two empirical papers, the other two papers in this sub-section are conceptual and synthesis articles. In Paper 10, the current literature on integrated assessments of climate change that combines ecological process based models with economic analyses was reviewed and a framework for such assessments with regard to bioenergy productions at local scale was constructed. The paper is based on the understanding that that bioenergy can significantly contribute to mitigate the negative effects of climate change, enhance energy security, and promote rural development (Henniges and Zeddies, 2006; GTZ, 2009). Thus, public pol- 


\section{Introduction}

icy and private investment around the globe are directed toward increasing local capacity to produce bioenergy (Khanna, 2008). Nevertheless, the potentials for using new plant varieties for biomass as an alternative energy source or as feedstock in an environmentally sustainable fashion remains to be demonstrated, since disturbing influences on land use decisions, on food prices, as well as on natural habitats due to use of bioenergy plants have been experienced (Scholz and Ellerbrock, 2002; Bechberger and Reiche, 2004; Hill et al., 2006; von Lampe, 2007; IFAD, 2008; Popp et al., 2011). Climate change is a global phenomenon but the effects are spatially and temporally different. The vulnerability to climate change varies from case to case and, thus, requires specific local mitigation and adaptation strategies. Given the broad uncertainties of climate change effects, assessing local economic impacts of climate change will enhance our understanding about how local communities can respond to climate change, and will highlight public policies or private choices that address or limit impacts. Therefore, the link between climate change and bioenergy potentials was conceptualized; key literature in this field was reviewed; and the challenges that the scientific communities are facing to build such a framework were discussed. The paper provides an opinion on the state-of-the-art of integrated ecological-economic assessments of climate change, as well as the challenges along with their implications faced in planning adaptation at local scale. It suggests that a much stronger effort must be made to meld natural science crop modeling approaches with economic analyses, to include spatially explicit consideration of conventional crop production along with 1st and 2nd generation bioenergy crops, and the evaluation not only of "best guess" scenarios of change, but also potential system impacts of extreme scenarios. To our understanding, there has been a very limited effort to perform integrated ecological-economic assessments of climate change linked with bioenergy potentials via a combined framework of crop growth simulation and economic evaluation in general and at local scale in particular.

From the literature review and our work presented so far, it is realized that our efforts are still limited in the sense that they are partial and consider only a few factors driving ecosystem changes and land use decision making. There are still a number of research gaps that need to be filled in, for example, as stated by Baumgärtner et al., (2006), it is not sufficient to just consider these two ecological and economic perspectives. Even taken together, the economic and ecological perspectives do not give a full and comprehensive picture of the interrelation between humans and nature. There are additional dimensions of the human being and its relation to nature (Becker and Manstetten, 2004; Becker, 2006). This includes, for example, slow changes that have occurred in regional social-ecological or human-environment systems, because such systems have a specific history (both social and biophysical) which has set the current scene, and critical thresholds may have occurred or may still occur that strongly influence regional ecosystem service outputs. Sustainable management should avoid net losses in ES and, therefore, requires detailed understanding of long-term changes in both social and biophysical drivers, their complex interactions in terms of impacts on ecosystem performance, 


\section{Introduction}

and their potential restriction of future trajectories of change, e.g., restrictions in relation to the implementation of management policies. Unraveling the long-term impacts of slowly changing drivers is key to understanding existing and potential communication among stakeholders across scales and social groups. Analytical traditions in the social sciences, in economics, and in ecosystem science provide us with partial frameworks within which to describe social/human ecological/environment systems only. While even within these partial frameworks critical simplifications are required, the major problem facing us today is how to profitably link together these differently constructed frameworks and relate them to potential global change impacts and long-term natural resource management (Tenhunen et al., 2015). Therefore, to make better decisions regarding ES trade-offs, a systematic account of the relationships between ecosystem management and the ES and values that it generates, is needed. This leads to the need to develop, based on various experimental efforts in a complex terrain in South Korea, a framework to study a classical trade-off in ES (provisioning of agricultural and forest products versus high quality water for public and industrial consumption). The basic question is on time dependent changes in spatial patterns of social-ecological systems that affect ES provision. The framework includes 10 adapted principles grouped in four themes, namely (i) long-term evolution of social-ecological systems, (ii) response of natural system, (iii) economic efficiencies and trade-offs in social-ecological systems, and (iv) sustainable management of key provisioning services. The historical and future trajectories in regional change, ecosystem processes, especially in farming areas that are hotspots of non-point water pollution, watershed level carbon, water and nutrient balances, economic gains and losses due to environmental impacts, environmental efficiencies, regional management efforts, and the educational approaches that would support a new paradigm in adaptive resource management were discussed. This framework develops and thus covers much more dimensions than that described above in Figure 2 and is summarized in Paper 11, which indicates that there are still many challenges due to the analytical complexity that require further integrated research to better support policy making for problem solving.

\subsection{Summary of research contribution}

Sustaining the supply and delivery of ES requires a deep understanding of the functioning of social/human-ecological/environment systems, the interactions of system components, and their responses to drivers of system changes in terms of gains and losses in ES. Therefore, the main analytical framework of this thesis is to use trade-off analyses in ES to provide useful implications. Given the commonly accepted notion that ecosystem services are products of social/human-ecological/environment systems, research in gains and losses of ecosystem services must be able to deal with both ecological and socio-economic systems, and thus demands an interdisciplinary approach. This is what the thesis has been tried to undertake in Part A. These analyses of trade-offs and drivers of changes in ES indicate that (i) private choices of land use alternatives, including crop selection, nutrient management practices, and farming techniques 


\section{Introduction}

at field, sub-watershed or local level can lead to synergies and trade-offs in ES, and (ii) the effects of climate variations and other drivers, both spatially and temporally, are still varied, even at a local scale. Therefore, the external effects of those choices must be taken into account to increase the social welfare. The challenge with regard to this point is that there are many effects and thus it is needed to find a way to represent them, instead of considering a specific effect separately. This is done in Part B.

Part B has extended the conventional ES trade-off framework in Part A with application of the economic efficiency concept to determine opportunity costs of resource use alternatives. It is not directly or explicitly related to a specific ES. Rather, it deals with the ecosystems (agricultural or forest ecosystems) as a whole; and thus facilitates a careful consideration in resource use decision making which is directly related to ES. The analyses in Part B show that agricultural intensification has led to a number of environmental externalities that need to be regulated as economic benefits are the main factors determining farmers' choice of land use and management practices; and there are economic and environmental trade-offs that need to be considered for sustainable development. These findings help identify the gainers and losers in welfare of different future development pathways. The understanding is that trade-off assessment is an operational tool for a quantitative approach to agricultural and environmental policy analysis and an essential ingredient in setting and designing relevant policies for sustainable agriculture. As land use processes are not static but dynamic and their external effects are thus also dynamic, depending on land use activities and their direct and indirect drivers of change, and there are critical threshold levels of such drivers at which the ecosystems can conserve their productive capacity and resilience. In this regard, environmental and economic efficiency analyses can provide a set of important information useful to relevant stakeholders (land users, policy makers, environmentalists, economists, etc.). In other words, the efficiency analysis can contribute a layer of required information to our current understanding on the dynamics of the regional social-ecological systems and improve the decision making processes towards more sustainable regional development. Part $\mathrm{C}$ of the thesis deals with implications for policy making and research, from payments for ES to institutions for ecosystem management, from an ecological - economic integration to a more comprehensive regional sustainable development perspective for sustainable acquisition of ES.

More specifically, from an empirical perspective, gains and losses in ES have been identified by (i) simulating nitrate leaching and private costs and benefits of management scenarios (Paper 1), and (ii) simulating water runoff regulation and private costs and benefits of land use scenarios (Paper 2); (iii) investigated the effects of climate variations on biomass accumulation (Paper 3), and farming techniques on soil erosion prevention (Paper 4); (iv) determining production efficiency measures and trade-offs between an economic and an environmental perspective (Papers 5 and 7) and drivers of environmental performance (Paper 6) and reforestation with a native tree species (Paper 7); (v) establishing a framework of output-based payments 


\section{Introduction}

for forest hydrological services (Paper 8) and discussing an effective property right system for forest ecosystem management (Paper 9). From a theoretical perspective, frameworks for ES assessments in relation to human well-being were constructed (Papers 10 and 11). 


\section{Introduction}

\section{References from the introduction section}

Abson, D.J.,von Wehrden, H., Baumgärtner, S., Fischer, J., Hanspach, J., Härdtle, W., Heinrichs, H., Klein, A.M., Lang, D.J., Martens, P., Walmsley, D., 2014. Ecosystem services as a boundary object for sustainability. Ecological Economics 103, 29-37.

Alberti, M., Asbjornsen, H., Baker, L.A., Brozovic, N., Drinkwater, L.E., Drzyzga, S.A., Jantz, C.A., Fragoso, J., Holland, D.S., Kohler, T.A., Liu, J., McConnell, W.J., Maschner, H.D.G., Millington, J.D.A., Monticino, M., Podestá, G., Pontius, R.G., Redman, C.L., Reo, N.J., Sailor, D., Urquhart, G., 2011. Research on Coupled Human and Natural Systems (CHANS): Approach, Challenges, and Strategies. Bulletin of the Ecological Society of America 92, 218-228.

Alcamo, J., van Vuuren, D., Ringler, C., Cramer, W., Masui, T., Alder, J., Schulze, K., 2005. Changes in nature's balance sheet: Model-based estimates of future worldwide ecosystem services. Ecology and Society 10, 19.

Angelsen, A., 2010. Policies for reduced deforestation and their impact on agricultural production. PNAS 107, 19639-19644.

Anthoff, D., Hepburn, C.J., Tol, R.S.J., 2009. Equity weighting and the marginal damage costs of climate change. Ecological Economics 68, 836-849.

Arnhold, S., Lindner, S., Lee, B., Martin, E., Kettering, J., Nguyen, T.T., Koellner, T., Ok, Y.S., Huwe, B., 2014. Conventional and organic farming: Soil erosion and conservation potential for row crop cultivation. Geoderma 219-220, 89-105

Asmild, M., Hougaard, J.L., 2006. Economic versus environmental improvement potentials of Danish pig farms. Agricultural Economics 35, 171-181.

Ausseil, A.G.E., Herzig, A., Dymond, J.R., 2012. Optimizing land use for multiple ecosystem service objectives: A case study in the Waitaki Catchment, New Zealand. Proceedings of the International Environmental Modelling and Software Society 6th Biennial Meeting, July 1-5 Leipzig, Germany.

Ayanu, Y.Z., Jentsch, A., Müller-Mahn, D., Rettberg, S., Romankiewicz, S., Koellner, T., 2015. Ecosystem engineer unleashed: Prosopis juliflora threatening ecosystem services? Regional Environmental Change 15, 155-167.

Ayanu, Y.Z., Nguyen, T.T., Marohn, C., Koellner, T., 2011. Crop production versus surface-water regulation: Assessing tradeoffs for land-use scenarios in the Tat Hamlet Watershed, Vietnam. International Journal of Biodiversity Science, Ecosystem Services \& Management 7, 231-244.

Bateman, I.J., Harwood, A.R., Mace, G.M., Watson, R.T., Abson, D.J., Andrews, B., Binner, A., Crowe, A., Day, B.H., Dugdale, S., Fezzi, C., Foden, J., Hadley, D., Haines-Young, R., Hulme, M., Kontoleon, R., Lovett, A.A., Munday, P., Pascual, U., Paterson, J., Perino, G., Sen, A., Siriwardena, G., van Soest, D., Termansen, M., 2013. Bringing ecosystem services into economic decision-making: Land use in the 


\section{Introduction}

United Kingdom. Science 341, 45-50.

Baumgärtner, S., Becker, C., Faber, M., Manstetten, R., 2006. Relative and absolute scarcity of nature: Assessing the roles of economics and ecology for biodiversity conservation. Ecological Economics 59, $487-498$.

Baumgärtner, S., Dyckhoff, H., Faber, M., Proops, J., Schiller, J., 2001. The concept of joint production and ecological economics. Ecological Economics 36, 365-372.

Baumgärtner, S., Quaas, M., 2009. Ecological-economic viability as a criterion of strong sustainability under uncertainty. Ecological Economics 68, 2008-2020.

Baumgärtner, S., Quaas, M., 2010a. What is sustainability economics? Ecological Economics 69, $445-450$.

Baumgärtner, S., Quaas, M., 2010b. Sustainability economics - general versus specific, and conceptual versus practical. Ecological Economics 69, 2056-2059.

Baumol, W.J., Oates, W.E., 1993. The theory of environmental policy: Externalities, public outlays, and the quality of life, $2^{\text {nd }}$ edition. Cambridge University Press. New York.

Baveye, P.C., Baveye, J., Gowdy, J., 2013. Monetary valuation of ecosystem services: It matters to get the timeline right. Ecological Economics 95, 231-235.

Bechberger, M., Reiche, D., 2004. Renewable energy policy in Germany: pioneering and exemplary regulations. Energy for Sustainable Development 8, 47-57.

Becker, C., 2006. The human actor in ecological economics: Philosophical approach and research perspectives. Ecological Economics 60, 17-23.

Becker, C., Faber, M., Hertel, K., Manstetten, R., 2005. Malthus vs. Wordsworth: perspectives on humankind, nature and economy: A contribution to the history and the foundations of ecological economics. Ecological Economics 53, 299-310.

Becker, C., Manstetten, R., 2004. Nature as a You: Novalis' philosophical thought and the modern ecological crisis. Environmental Values 13, 101-118.

Bennett, E.M., Balvanera, P., 2007. The future of production systems in a globalized world. Frontiers in Ecology and the Environment 5, 191-198.

Bennett, E.M., Peterson, G.D., Gordon, L., 2009. Understanding relationships among multiple ecosystem services. Ecological Letters 12, 1394-1404.

Berkes, F., Folke, C., 1998. Linking sociological and ecological systems: management practices and social mechanisms for building resilience. Cambridge University Press, New York.

Bernués, A., Ruiz, R., Olaizola, A., Villalba, D., Casasús, I., 2011. Sustainability of pasture-based livestock farming systems in the European Mediterranean context: synergies and trade-offs. Livestock Science 139, 44-57. 


\section{Introduction}

Börkey, P., Cassar, A., Meadors, L., et al., 2005. Freshwater ecosystem services. In: Chopra, K., Leemans, R., Kumar, P. (eds.) Ecosystems and human well-being: Policy responses: Findings of the responses working group, Volume 3 Millennium ecosystem assessment, Island Press.

Bose, P., Arts, B., van Dijk, H., 2012. 'Forest governmentality': A genealogy of subject-making of forest-dependent 'scheduled tribes' in India. Land Use Policy 29, 664-673.

Bowyer, C., 2010. Anticipated indirect land use change associated with expanded use of biofuels and bioliquids in the EU - An analysis of the National Renewable Energy Action Plans. Institute for European Environmental Policy, Brussels.

Boyd, J., Banzhaf, S., 2007. What are ecosystem services? The need for standardized environmental accounting units. Ecological Economics 63, 616-626.

Brauman, K.A., Daily, G.C., Ka'eo Duarte, T., Mooney, H.A., 2007. The nature and value of ecosystem services: An overview highlighting hydrologic services. Annual Review of Environment and Resources $32,67-98$

Brookshire, D.S., Brand, A., Thacher, J., Dixon, M.D., Benedict, K., Stromberg, J.C., Lansey, K., Goodrich, D.C., Mcintosh, M., Grady, J., Stewart, S., Broadbent, C., Izon, G., 2007. Integrated modeling and ecological valuation: Applications in the Semi-Arid Southwest. Proceedings of the USEPA "Valuation for Environmental Policy: Ecological Benefits" workshop, April 23- 24. Washington D.C.

Brouwer, R., Hofkes, M., 2008. Integrated hydro-economic modelling: Approaches, key issues and future research directions. Ecological Economics 66, 1622.

Brouwer, R., van Ek, R., 2004. Integrated ecological, economic and social impact assessment of alternative flood control policies in the Netherlands. Ecological Economics 50, 1- 21.

Brown, D., Stephens, E., Ouma, J., Murithi, F., Barrett, C., 2006. Livelihood strategies in the rural Kenyan highlands. African Journal of Agricultural and Resource Economics 1, 21-36.

Bryan, B.A., King, D., Wang, E., 2010. Biofuels agriculture: landscape-scale trade-offs between fuel, economics, carbon, energy, food, and fiber. Global Change Bioenergy 2, 330-345.

Callens, I., Tyteca, D., 1999. Towards indicators of sustainable development for firms: A productive efficiency perspective. Ecological Economics 28, 41-53.

Canadell, J.G., Le Quéré, C., Raupach, M.R., Field, C.B., Buitenhuis, E.T., Ciais, P., Conway, T.J., Gillett, N.P., Houghton, R.A., Marland, G., 2007. Contributions to accelerating atmospheric $\mathrm{CO}_{2}$ growth from economic activity, carbon intensity, and efficiency of natural sinks. PNAS 104, 18866-18870.

Cardinale, B.J., Duffy, J.E., Gonzalez, A., Hooper, D.U., Perrings, C., Venail, P., Narwani, A., MacE, G.M., Tilman, D., Wardle, D.A., Kinzig, A.P., Daily, G.C., Loreau, M., Grace, J.B., Larigauderie, A., Srivastava, D.S., Naeem, S., 2012. Biodiversity loss and its impact on humanity. Nature 486, 59-67.

Carney, D., 2002. Sustainable livelihoods approaches: Progress and possibilities for change. Department 


\section{Introduction}

for International Development. London.

Carpenter, S.R., Folke, C., Norström, A., Olsson, O., Schultz, L., Agarwal, B., Balvanera, P., Campbell, B., Castilla, J.C., Cramer, W., DeFries, R., Eyzaguirre, P., Hughes, T.P., Polasky, S., Sanusi, Z., Scholes, R., Spierenburg, M., 2012. Program on ecosystem change and society: An international research strategy for integrated social-ecological systems. Current Opinion in Environmental Sustainability 4, 134-138.

Carreno, L., Frank, F.C., Viglizzo, E.F., 2012. Tradeoffs between economic and ecosystem services in Argentina during 50 years of land-use change. Agriculture, Ecosystems \& Environment 154, 68-77.

Chambers, R., Conway, G., 1992. Sustainable rural livelihoods: practical concepts for the 21st century. Institute of Development Studies Discussion Paper 296. Brighton.

Chang, M., 2006. Forest Hydrology: An introduction to water and forests. CRC Press.

Chazdon, R.L., 2008. Beyond deforestation: Restoring forests and ecosystem services on degraded lands. Science 320, 1458-1460.

Chisholm, R. A., 2010. Tradeoffs between ecosystem services: water and carbon in a biodiversity hotspot. Ecological Economics 69, 1973-1987.

Coase, R., 1998. The new institutional economics. American Economic Review 88, 72-74.

Coase, R., 1960. The problem of social cost. Journal of Law and Economics 3, 1-44.

Coelli, T., Lauwers, L., Van Huylenbroeck, G., 2007. Environmental efficiency measurement and the materials balance condition. Journal of Productivity Analysis 28, 3-12.

Costanza, R., D’Arge, R., De Groot, R., Farber, S., Grasso, M., Hannon, B., Limburg, K., Naeem, S., O'Neill, R.V., Paruelo, J., Raskin, R.G., Sutton, P., Belt, M., 1997. The value of the world's ecosystem services and natural capital. Nature 387, 253-260.

Costanza, R., Wainger, R., Folke, C., Mäler, K-G., 1993. Modeling complex ecological economic systems: toward an evolutionary, dynamic understanding of people and nature. BioScience 43, 545-555.

Cumming, G., Peterson, G., 2005. Ecology in global scenarios. In: Carpenter, S.R., Pingali, P.L., Bennett, E.M., Zurek, M.B. (eds.): Ecosystems and human well-being: Scenarios, Volume 2. Findings of the Scenarios Working Group, Millennium Ecosystem Assessment. Island Press, Washington, D.C. pp. $45-70$.

Daily, G. C., Polasky, S., Goldstein, J., Kareiva, P.M., Mooney, H.A., Pejchar, L., Ricketts, T.H., Salzman, J., Shallenberger, R., 2009. Ecosystem services in decision making: Time to deliver. Frontiers in Ecology and the Environment 7, 21-28. Daily, G.C., 1997. Nature's services: Societal dependence on natural ecosystems. Island Press, Washington, D.C.

de Baan, L., Alkemade, R., Koellner, T., 2013. Land use impacts on biodiversity in LCA: A global approach. International Journal of Life Cycle Assessment 18, 1216-1230.

de Groot, R.S., 1987. Environmental functions as a unifying concept for ecology and economics. The 


\section{Introduction}

Environmentalist 7, 105-109.

de Groot, R.S., 2006. Function-analysis and valuation as a tool to assess land use conflicts in planning for sustainable, multi-functional landscapes. Landscape and Urban Planning 75, 175-186.

de Groot, R.S., Alkemade, R., Braat, L., Hein, L., Willemen, L., 2010. Challenges in integrating the concept of ecosystem services and values in landscape planning, management and decision making. Ecological Complexity 7, 260-272.

de Groot, R.S., Wilson, M.A., Boumans, R.M.J., 2002.A typology for the classification, description and valuation of ecosystem function, goods and services. Ecological Economics 41, 393 - 408.

Debertin, D.L., 2012. Applied microeconomics: Consumption, production and markets. University of Kentucky.

Debreu, G., 1959. Theory of value: An axiomatic analysis of economic equilibrium. Wiley, New York.

Delacote, P., 2012. Forests and development: Local, national and global issues. PhD thesis, the European University Institute.

Demsetz, H., 1967. Towards a theory of property rights. American Economic Review 57, 347-59.

Dimitrov, R., S., 2005. Hostage to norms: States, institutions and global forest politics. Global Environmental Politics 5, 1-24.

Drechsler, M., Grimm, V., Mysiak, J., Wätzold, F., 2007. Differences and similarities between economic and ecological models for biodiversity conservation. Ecological Economics 62, 232-241.

Drechsler, M., Johst, K., Wätzold, F., Shogren, J. F., 2010. An agglomeration payment for cost-effective biodiversity conservation in spatially structured landscapes. Resource and Energy Economics 32, 261275.

Drechsler, M., Wätzold F., 2007. Ecological-economic modelling for the sustainable use and conservation of biodiversity. Ecological Economics 62, 203-206.

Drechsler, M., Wätzold, F., 2009. Applying tradable permits to biodiversity conservation: Effects of space-dependent ecological benefits and cost heterogeneity on habitat allocation. Ecological Economics 68, 1083-1092.

Eatwell, J., Milgate, M., Newman, R., 1987. A dictionary of economics, 4 vols. Macmillan, London.

Egoh, B.N., O’Farrell, P.J., Koellner, T., Charef, A., Gurney, L.J., Abi, H.N., Egoh, M., Willemen, L., 2012. An African account of ecosystem service provision: use, threats and policy options for sustainable livelihoods. Ecosystem Services 2, 71-81.

Elmqvist, T., Tuvendal, M., Krishnaswamy, J., Hylander, K., 2011. Managing trade-offs in ecosystem services. Ecosystem Services Economics Working Paper Series No. 4. The United Nations Environment Programme. 


\section{Introduction}

Elmqvist, T., Tuvendal, M., Krishnaswamy, J., Hylander, K., 2010. Ecosystem services: managing trade-offs between provisioning and regulating services. In: P. Kumar (eds.): Valuation of regulating services: from theory to practice. Routledge UK.

Engel, S., Pagiola, S., Wunder, S., 2008. Designing payments for environmental services in theory and practice: An overview of the issue. Economics 65, 663-674.

Faber, M., Manstetten, R., 1998. Philosophische Grundlagen von Ökonomie und Ökologie, Lecture notes, Department of Economics, University of Heidelberg.

Faber, M., Manstetten, R., Müller, G., 1994. Interdisziplinäre Umweltforschung aus ökonomischer Sicht. Naturwissenschaften 81, 193-199.

FAO (Food and Agriculture Organization), 2010. Global forest resources assessment 2010. Rome.

Farber, S., Costanza, R., Wilson, M., 2002. Economic and ecological concepts for valuing ecosystem services. Ecological Economics 41, 375-392.

Färe, R., Grosskopf, S., Lovell, C.A.K., Pasurka, C., 1989. Multilateral productivity comparisons when some outputs are undesirable: A nonparametric approach. Review of Economics and Statistics 71, 90-98.

Färe, R., Grosskopf, S., Pasurka, J.C.A., 2007. Environmental production functions and environmental directional distance functions. Energy 32, 1055-1066.

Färe, R., Grosskopf, S., Tyteca, D., 1996. An activity analysis model of the environmental performance of firms-application to fossil-fuel-fired electric utilities. Ecological Economics 18, 161-175.

Farley, J., 2012. Ecosystem services: The economic debates. Ecosystem Services 1, 40-49.

Fisher B. S., Nakicenovic, N., Alfsen, K., Morlot, J.C., de la Chesnaye, F., Hourcade, J.C., Jiang, K., 2007. Issues related to mitigation in the long-term context. In Metz B., Davidson, O. R., Bosch P. R., Dave R., Meyer L. A. (eds.): Climate change 2007: Mitigation. Cambridge University Press, Cambridge and New York.

Fisher, B., Turner, K.R., Morling, P., 2009. Defining and classifying ecosystem services for decision making. Ecological Economics 68, 643-653.

Fisher, J. A., Brown, K., 2014. Ecosystem services concepts and approaches in conservation: just a rhetorical tool? Ecological Economics 108, 257-265.

Foley, J.A., Defries, R., Asner, J.P., Barford, C., Bonan, G., Carpenter, S.R., Chapin, F.S., Coe, M.T., Daily, G.C., Gibbs, H.K., Helkowski, J.H., Holloway, T., Howard, E.A., Kucharik, C.J., Monfreda, C., Patz, J.A., Prentice, I.C., Ramankutty, N., Snyder, P.K., 2005. Global consequences of land use. Science $309,570-574$.

Folke, C., Carpenter, S., Walker, B., Scheffer, M., Elmqvist, T., Gunderson, L., Holling, C.S., 2004. Regime shifts, resilience, and biodiversity in ecosystem management. Annual Review of Ecology and Systematics $35,557-581$. 


\section{Introduction}

Fried, H., Lovell, C.A.K., Schmidt, S., 2008. The measurement of productive efficiency and productivity growth, Oxford University Press, Oxford.

Frondel, M., Lehmann, P., Wätzold, F., 2012. The impact of information on landowners' participation in voluntary conservation programs: Theoretical considerations and empirical evidence from an agrienvironment program in Saxony, Germany. Land Use Policy 29, 388-394.

Galat, D. L., Berkley, J., 2014. Introduction to exploring opportunities for advancing collaborative adaptive management (CAM): Integrating experience and practice. Ecology and Society 19, 40.

García-Amado, L.R., Pérez, M.R., Escutia F.R., García S.B., Mejía E.C., 2011. Efficiency of payments for environmental services: Equity and additionality in a case study from a biosphere reserve in Chiapas, Mexico. Ecological Economics 70, 2361-2368.

Giannakas, K., Tran, K.C., Tzouvelekas, V., 2003. On the choice of functional form in stochastic frontier modeling. Empirical Economics 28, 75-100.

Gómez-Baggethun, E., de Groot, R., Lomas, P.L., Montes, C., 2010. The history of ecosystem services in economic theory and practice: from early notions to markets and payment schemes. Ecological Economics 69, 1209-1218.

GTZ (German Technical Cooperation), 2009. Economic approaches to climate change adaptation and their role in project prioritisation and appraisal. Eschborn.

Haase, D., Schwarz, N., Strohbach, M., Kroll, F., Seppelt, R., 2012. Synergies, trade-offs, and losses of ecosystem services in urban regions: an integrated multiscale framework applied to the Leipzig-Halle Region, Germany. Ecology and Society 17, 22.

Hagedorn, K., 2008. Particular requirements of institutional analysis in nature-related sectors. European Review of Agricultural Economics 35, 357-384.

Hailu A., Veeman, T.S., 2001. Non-parametric productivity analysis with undesirable outputs: An application to the Canadian pulp and paper industry. American Journal of Agricultural Economics 83, 605-616.

Halpern, B.S., Walbridge, S., Selkoe, K.A., Kappel, C.V., Micheli, F., D’Agrosa, C., Bruno, J.F., Casey, K.S., Ebert, C., Fox, H.E., Fujita, R., Heinemann, D., Lenihan, H.S., Madin, E.M.P., Perry, M.T., Selig, E.R., Spalding, M., Steneck, R., Watson, R., 2008. A global map of human impact on marine ecosystems. Science 319, 948-952.

Hartwick, J., 2000. National accounting and capital. Edward Elgar, Northampton.

Häyhä, T., Franzese, P.P., 2014. Ecosystem services assessment: A review under an ecological-economic and systems perspective. Ecological Modelling 289, 124-132.

Heal, G., 2007. Environmental accounting for ecosystems. Ecological Economics 61, 693-694.

Heal, G.M., Barbier, E.B., Boyle, K.J., Covich, A.P., Gloss, S.P., Hershner, C.H., Hoehn, J.P., Pringle, 


\section{Introduction}

C.M., Polasky, S., Segerson, K., Shrader-Frechette, K., 2005. Valuing ecosystem services: toward better environmental decision making. The National Academies Press, Washington, D.C.

Hein, L., 2010. Economics and ecosystems, efficiency, sustainability and equity in ecosystem management. Edward Elgar. Cheltenham.

Heinz, I., Pulido-Velazquez, M., Lund, J. Andreu, J., 2007. Hydro-economic modeling in river basin management: Implications and applications for the European Water Framework Directive. Water Resources Management 21,1103-1125.

Henniges, O., Zeddies, J., 2006. Bioenergy and Agriculture: Promises and Challenges. Focus 14, Brief 9-12. International Food Policy Research Institute (IFPRI), Washington, D.C.

Herzig, A., Ausseil, A.G.E., Dymond, J.R., 2013. Spatial optimisation of ecosystem services. In Dymond, J.R. (eds.): Ecosystem Services in New Zealand - conditions and trends. Manaaki Whenua Press, Lincoln, New Zealand.

Hewlett, J.D., 1982. Principles of forest hydrology. University of Georgia Press. Athens.

Hill, J., Nelson, E., Tilman, D., Polaskz, S., Tiffany, D., 2006. Environmental, economic, and energetic costs and benefits of biodiesel and ethanol biofuels. PNAS 103, 11206-11210.

Hoang, V., Nguyen, T.T., 2013. Analyses of environmental efficiency variations: A nutrient balance approach. Ecological Economics 86, 37-46.

Holling, C. S., 2001. Understanding the complexity of economic, ecological, and social systems. Ecosystems $4,390-405$.

Holzkämper, A., Seppelt, A., 2007. LUPOlib - A generic library for optimising land-use patterns and landscape structures. Environmental Modelling \& Software 22, 1801-1804.

Hooper, D.U., Chapin, F.S., Ewel, J.J., Hector, A., Inchausti, P., Lavorel, S., Lawton, J.H., Lodge, D.M., Loreau, M., Naeem, S., Schmid, B., Setala, H, Symstad, A.J., Vandermeer, J., Wardle, D.A., 2005. Effects of biodiversity on ecosystem functioning: a consensus of current knowledge. Ecological Monographs 75, 3-35.

Howarth, R., 2007. Towards an operational sustainability criterion. Ecological Economics 63, 656-663.

Humphreys, D., 2011. International forest politics, in G. Kütting (eds.): Global environmental politics: Concepts, theories and case studies. Routledge. London.

ICSU, UNESCO, UNU, 2008. Ecosystem change and human well-being: Research and monitoring. Report, Paris.

IEA (International Energy Agency), 2008. Annual report 2008. New Zealand.

IFAD (International Fund for Agricultural Development), 2007. Climate change: policy issues and options for IFAD. Rome. 


\section{Introduction}

IFAD, 2008. Biofuel expansion: Challenges, risks and opportunities for rural poor people: How the poor can benefit from this emerging opportunity. Rome.

Illukpitiya, P., Yanagida, J.F., 2010. Farming vs. Forests: Trade-off between agriculture and extraction of non-timber forest products. Ecological Economics 69, 1952-1963.

IPCC (Intergovernmental Panel on Climate Change), 2007. Climate change 2007: Impacts, adaptation and vulnerability. Contribution of Working Group II to the Fourth Assessment Report of the Intergovernmental Panel on Climate Change. Cambridge University Press, Cambridge.

IPCC, 2012. Renewable energy sources and climate change mitigation - Special Report of the Intergovernmental Panel on Climate Change, in Edenhofer, O., Madruga, R.P., Sokona, Z., Seyboth, K., Matschoss, P., Kadner, S., Zwickel, T. (eds.): Climate Policy. Cambridge University Press, Cambridge. Jax, K., Barton, D.N., Chan, K.M.A., de Groot, R., Doyle, U., Eser, U., Görg, C., Gómez-Baggethun, E., Griewald, Y., Haber, W., Haines-Young, R., Heink, U., Jahn, T., Joosten, H., Kerschbaumer, L., Korn, H., Luck, G.W., Matzdorf, B., Muraca, B., Neßhöver, C., Norton, B., Ott, K., Potschin, M., Rauschmayer, F., von Haaren, C., Wichmann, S., 2013. Ecosystem services and ethics. Ecological Economics 93, 260-268.

Johnston, J.M., McGarvey, D.J., Barber, M.C., Laniak, G., Babendreier, J., Parmar, R., Wolfe, K., Kraemer, S.R., Cyterski, M., Knightes, C., Rashleigh, B., Suarez, L., Ambrose, R., 2011. An integrated modeling framework for performing environmental assessments: Application to ecosystem services in the Albemarle-Pamlico basins (NC and VA, USA). Ecological Modelling 222, 2471-2484.

Johst, K., Drechsler, M., van Teeffelen, A.J.A., Hartig, F., Vos, C.C., Wissel, S., Wätzold, F., Opdam, P., 2011. Biodiversity conservation in dynamic landscapes: trade-offs between number, connectivity and turnover of habitat patches. Journal of Applied Ecology 48, 1227-1235.

Kabat, P., Claussen, M., Dirmeyer, P.A., Gash, G.H., de Guenni, L.B., Pielke, R.A., Vörömarty, C.J., Hutjes, R.W.A., Lütkemeier, S., 2004. Vegetation, water, humans and the climate. Springer-Verlag, Berlin-Heidelberg-New York, pp. 566.

Kareiva, P., Watts, S., McDonald, R., Boucher, T., 2007. Domesticated nature: shaping landscapes and ecosystems for human welfare. Science 316, 1866-1869.

Keen, E. C., 2014.Tradeoffs in bacteriophage life histories. Bacteriophage 4, e28365,doi:10.4161/bact.28365.

Khanna, M., 2008. Land use and GHG implications of meeting biofuel targets: Linking biophysical and economic models. Paper presented at the Conference Linking biophysical and economic models of biofuel production and environmental impacts, November 13th -14th, Gleacher Center, Chicago, IL.

Kirchner, M., Schmidt, J., Kindermann, G., Kulmer, V., Mitter, H., Prettenthaler, F., Rudisser, J., Schauppenlehner, T., Schonhart, M., Strauss, F., Tappeiner, U., Tasser, E., Schmid, E., 2015. Ecosystem services and economic development in Austrian agricultural landscapes - the impact of policy and climate change scenarios on trade-offs and synergies. Ecological Economics 109, 161-174. 


\section{Introduction}

Kiss, A., 2004. Making biodiversity conservation a land use priority. In T. McShane and M. Wells (eds.): Getting biodiversity projects to work: Towards more effective conservation and development. Columbia University Press, New York.

Klain, S.C., Satterfield, T.A., Chan, K.M.A., 2014. What matters and why? Ecosystem services and their bundled qualities. Ecological Economics 107, 310-320.

Koellner, T., 2010. Ecosystem services in human-environment systems: Modeling land use, biodiversity and ecosystem services, market actors' decision-making, and financial mechanisms. Habilitation Thesis, ETH Zürich.

Koellner, T., Geyer, R., 2013. Global land use assessment on biodiversity and ecosystem services in Life Cycle Assessment. International Journal of Life Cycle Assessment 18, 1185-1187.

Koellner, T., Sell, J., Navarro, G., 2010. Why and how much are firms willing to invest in ecosystem services from tropical forests? A comparison of international and Costa Rican firms. Ecological Economics $69,2127-2139$

Kortelainen, M., 2008. Dynamic environmental performance analysis: A Malmquist index approach. Ecological Economics 64, 701-715.

Kosoy, N., Martinez-Tuna, M., Muradian, R., Martinez-Alier, J., 2007. Payments for environmental services in watersheds: insights from a comparative study of three cases in Central America. Ecological Economics 61, 446-455.

Kragt, M.E., Robertson, M.J., 2014. Quantifying ecosystem services trade-offs from agricultural practices. Ecological Economics 102, 147-157.

Kremen, C., Miles, A., 2012. Ecosystem services in biologically diversified versus conventional farming systems: benefits, externalities, and trade-offs. Ecology and Society 17, 40.

Krieger, D.J., 2001. Economic value of forest ecosystem services: A review. The Wilderness Society. Washington, D.C.

Kumar, P., Brondizio, E., Gatzweiler, F., Gowdy, J., De Groot, D., Pascual, U., Reyers, B., Sukhdev, P., 2013. The economics of ecosystem services: from local analysis to national policies. Current Opinion in Environmental Sustainability 5, 78-86.

Kuosmanen, T., Kortelainen, M., 2005. Measuring eco-efficiency of production with data envelopment analysis. Journal of Industrial Ecology 9, 59-72.

La Notte, A., Camino, L., Bruna, G., Joachim, M., Benis, E., Marialuisa, P., 2015. An ecologicaleconomic approach to the valuation of ecosystem services to support biodiversity policy: A case study for nitrogen retention by Mediterranean rivers and lakes. Ecological Indicators 48, 292-302.

Lambini, C.K., Nguyen, T.T., 2014. A comparative analysis of the effects of institutional property rights on forest livelihoods and forest conditions: Evidence from Ghana and Vietnam. Forest Policy and 


\section{Introduction}

Economics 38, 178-190.

Landell-Mills, N., Porras, I.T., 2002. Silver bullet or fool's gold?A global review of markets for forest environmental services and their impact on the poor. International Institute for Environment and Development, London, UK.

Lapola, D.M., Schaldach, R., Alcamo, J., Bondeau, A., Koch, J., Koelking, C., Joerg, A., Priess, J.A., 2010. Indirect land-use changes can overcome carbon savings from biofuels in Brazil. PNAS 107, 3388-3393

Lautenbach, S., Seppelt, R., Liebscher, J., Dormann, C.F., 2012. Spatial and temporal trends of global pollination benefit. PLoS ONE, doi:10.1371/journal.pone.0035954.

Lautenbach, S., Volk, M., Strauch, M., Whittaker, G., Seppelt, R., 2013. Optimization-based trade-off analysis of biodiesel crop production for managing an agricultural catchment. Environmental Modelling \& Software 48, 98-112.

Lauwers, L., 2009. Justifying the incorporation of the materials balance principle into frontier-based eco-efficiency models. Ecological Economics 68, 1605-1614.

Lehmann, C.E.R., Ratnam, J., Hutley, B., 2009. Which of these continents is not like the other? Comparisons of tropical savanna systems: Key questions and challenges. New Phytologist 181, 508-511. Lester, S., Costello, C., Halpern, B.S., Gaines, S.D., White, C., Barth, J.A., 2013. Evaluating trade-offs among ecosystem services to inform marine spatial planning. Marine Policy 38, 80-89.

Loos, J., Abson, D.J., Chappell, M.J., Hanspach, J., Mikulcak, F., Tichit, M., Fischer, J., 2014. Putting meaning back into sustainable intensification. Frontiers in Ecology and the Environment 12, 356-361.

Losey, J.E., Vaughan, M., 2006. The economic value of ecological services provided by insects. BioScience $56,311-323$.

MA (Millennium Ecosystem Assessment), 2003. Ecosystems and human well-being: A framework for assessment. Island Press, Washington, D.C.

MA, 2005. Ecosystems and human well-being: Synthesis Report. World Resources Institute, Washington, D.C.

Mankiw, N.G., 2012. Macroeconomics, $8^{\text {th }}$ Edition.Worth Publishers, New York.

Marohn, C., 2008. User Manual for Land Use Change Impact Assessment Model (LUCIA). University of Hohenheim.

McKechnie, J., Colombo, S., Chen, J., Mabee, W., MacLean, H.L., 2011. Forest bioenergy or forest carbon? Assessing trade-offs in greenhouse gas mitigation with wood-based fuels. Environmental Science \& Technology 45, 789-795.

Mendelsohn, R., Olmstead, S., 2009. The economic valuation of environmental amenities and disamenities: methods and applications. Annual Review of Environment and Resources 34, 325-347. 


\section{Introduction}

Meyfroidt, P., Lambin, E., 2011. Global Forest Transition: Prospects for an end to deforestation. Annual Review of Environment and Resources 36, 343-371.

Mimouni, M., Zekri, S., Flichman, G., 2000. Modelling the trade-offs between farm income and the reduction of erosion and nitrate pollution. Annals of Operations Research 94, 91-103.

Mitsch, W.J., Tejada, J., Nahlik, A.M., Kohlmann, B., Bernal, B., Hernandez, C.E., 2008. Tropical wetlands for climate change research, water quality management and conservation education on a university campus in Costa Rica. Ecological Engineering 34, 276-288.

Mueller, N.D., West, P.C., Gerber, J.S., MacDonald, G.K., Polasky, S., Foley, J.A., 2014. A tradeoff frontier for global nitrogen use and cereal production. Environmental Research Letters 9, no.5: 054002. Nagendra, H., 2007. Drivers of reforestation in human-dominated forests. PNAS 104, 15218-15223.

Nelson, E., Mendoza, G., Regetz, J., Polasky, S., Tallis, H., Cameron, D. R., Chan, K. M. A., Daily, G. C., Goldstein, J., Kareiva, P. M., Lonsdorf, E., Naidoo, R., Ricketts, T. H., Shaw, M. R., 2009. Modeling multiple ecosystem services, biodiversity conservation, commodity production, and tradeoffs at landscape scales. Frontiers in Ecology and the Environment 7, 4-11.

Neumayer, E., 2003. Weak versus strong sustainability: Exploring the limits of two opposing paradigms. Edward Elgar, Cheltenham.

Neumayer, E., 2007. A missed opportunity: The Stern Review on climate change fails to tackle the issue of non-substitutable loss of natural capital. Global Environmental Change 17, 297-303.

Nguyen, T. T., 2008. The impact of land reform on farm households in the Northern Uplands of Vietnam. Margraf Publishers, Weikersheim.

Nguyen, T. T., Bauer, S., Uibrig, H., 2010. Land privatization and afforestation incentive of rural farms in the Northern Uplands of Vietnam. Forest Policy and Economics 12, 518-526.

Nguyen, T.T, Pham, V.D., Tenhunen, J., 2013. Linking regional land use and payments for forest hydrological services: A case study of HoaBinh Reservoir in Vietnam. Land Use Policy 33, 130-140.

Nguyen, T.T., Tenhunen, J., 2013. Review of integrated ecological-economic analyses for bioenergy plants under climate change at local scale. International Journal of Climate Change Strategies and Management 5, 324-343

Nguyen, T.T., 2012. Land privatization and farm production in the Northern Uplands of Vietnam. Asian Economic Journal 26, 413-421.

Nguyen, T.T., Hoang, V.N., Seo, B., 2012. Cost and environmental efficiency of rice farms in South Korea. Agricultural Economics 43, 367-376.

Nguyen, T.T., Koellner, T., Le, Q.B., Lambini, C.L., Choi, I., Shin, H., Pham, V.D., 2014b. An economic analysis of reforestation with a native tree species: The case of Vietnamese farmers. Biodiversity and Conservation 23, 811-830. 


\section{Introduction}

Nguyen, T.T., Ruidish, M.,Koellner, T., Tenhunen, J., 2014a. Synergies and trade-offs between nitrate leaching and net farm income: The case of best nitrogen management practices in South Korea. Agriculture, Ecosystems \& Management 186, 160-169.

Nielsen, J., Rayamajhi, S., Uberhuaga, P., Meilby, H., Smith-Hall, C., 2013. Quantifying rural livelihood strategies in developing countries using an activity choice approach. Agricultural Economics 44, 57-71.

Ninan, K.N., Inoue, M., 2013. Valuing forest ecosystem services: What we know and what we don't. Ecological Economics 93, 137-149.

Nordhaus, W.D., 2010. Economic aspects of global warming in a post-Copenhagen environment. PNAS $106,11721-11726$.

Norgaard, R., 2010. Ecosystem services: From eye-opening metaphor to complexity blinder. Ecological Economics 69, 1219-1227.

Norton, B.G., Toman, M.A., 1997. Sustainability: ecological and economic perspectives. Land Economics $73,553-568$.

NRC (National Research Council Committee on Sustainability Linkages in the Federal Government), 2013. Sustainability for the Nation: Resource connections and governance linkages. National Academies Press, Washington, D.C.

Ohl, C., Drechsler, M., Johst, K., Wätzold, F., 2008. Compensation payments for habitat heterogeneity: Existence, efficiency, and fairness considerations. Ecological Economics 67, 162-174.

Olschewski, R., Klein, A.M., 2011. Ecosystem services between sustainability and efficiency. Sustainability 7, 69-73.

Ostrom, E., 1990. Governing the commons: The evolution of institutions for collective action. Cambridge University Press, Cambridge.

Ostrom, E., 2005. Understanding institutional diversity. Princeton University Press, Princeton.

Oude Lansink, A., Silva, E., 2003. $\mathrm{CO}_{2}$ and energy efficiency of different heating technologies in the Dutch glasshouse industry. Environmental and Resource Economics 24, 395-407.

Oude Lansink, A., Wall, A., 2014. Frontier models for evaluating environmental efficiency: an overview. Economic Business Letter 3, 43-50.

Pagiola, S., 2008. Payments for environmental services in Costa Rica. Ecological Economics 65,712-724. Pagiola, S., Arcenas, A., Platais, G., 2005. Can payments for environmental services help reduce poverty? An exploration of the issues and the evidence to date from Latin America. World Development 33, 237253.

Pagiola, S., Landell-Mills, N., Bishop, J., 2002. Making market-based mechanisms work for forests and people. In Pagiola, S., Bishop, J., Landell-Mills, N. (eds.): Selling forest environmental services: market-based mechanisms for conservation and development, Earthscan, London, pp. 261-290. 


\section{Introduction}

Pagiola, S., Platais, G., 2007. Payments for environmental services: From theory to practice. The World Bank. Washington, D.C.

Paterson, S.E., Bryan, B.A., 2012. Food-carbon trade-offs between agriculture and reforestation and the efficiency of market-based policies. Ecology and Society 17, 21.

Pearce, D., Moran, D., 1994. The economic value of biodiversity. Earthscan, London. 296 pp.

Pereira, H.M.,Reyers, B., Watanabe, M., Bohensky, E., Foale, S., Palm, C., Espaldon, M.V., Armenteras, D., Tapia, M., Rincón, A., Lee, M.J., Patwardhan, A., Gomes, I., 2005. Condition and trends of ecosystem services and biodiversity. In: Capistrano, D., Samper, C., Lee, M.J., Raudsepp-Hearne, C. (eds.): Ecosystems and human well-being: multi scale assessments, Volume 4. Findings of the Sub-global Assessments Working Group of the Millennium Ecosystem Assessment. Island Press, Washington, DC., pp. 171-203.

Petz, K., Minca, E.L., Werners, S.E., Leemans, R., 2012. Managing the current and future supply of ecosystem services in the Hungarian and Romanian Tisza River Basin. Regional Environmental Change $12,689-700$.

Picazo-Tadeo, A.J., Beltrán-Esteve, M., Gómez-Limón, J.A., 2012. Assessing eco-efficiency with directional distance functions. European Journal of Operational Research 220, 798-809.

Picazo-Tadeo, A.J., Gómez-Limón, J.A., Reig-Martínez, E., 2011. Assessing farming eco-efficiency: A data envelopment analysis approach. Journal of Environmental Management 92, 1154-1164.

Piot-Lepetit, I., Le Moing, M., 2007. Productivity and environmental regulation: the effect of the nitrates directive in the French pig sector. Environmental and Resource Economics 38, 433-46.

Plevin, R.J., O'Hare, M., Jones, A.D., Torn, M.S., Gibbs, H.K., 2010. Greenhouse gas emissions from biofuels' indirect land use change are uncertain but may be much greater than previously estimated. Environmental Science \& Technology 44, 8015-8021.

Polasky, S., Lewis, D.J., Planting, A.J., Nelson, E., 2014. Implementing the optimal provision of ecosystem services. PNAS 111, 6248-6253.

Polasky, S., Nelson, E., Camm, J., Csuti, B., Fackler, P., Lonsdorf, E., Montgomery, C., White, D., Arthur, J., Garber-Yonts, B., Haight, B., Kagan, J., Starfield, A., Tobalske, C., 2008. Where to put things? Spatial land management to sustain biodiversity and economic returns. Biological Conservation $141,1505-1524$.

Polasky, S., Nelson, E., Pennington, D., Johnson, K.A., 2011. The impact of land-use change on ecosystem services, biodiversity and returns to landowners: A case study in the state of Minnesota. Environmental and Resource Economics 48, 219-242.

Popp, A., Dietrich, J. P., Lotze-Campen, H., Klein, D., Bauer, N., Krause, M., Beringer, T., 2011. The economic potential of bioenergy for climate change mitigation with special attention given to implications for the land system. Environmental Research Letters 6, doi:10.1088/1748-9326/6/3/034017 


\section{Introduction}

Poppenborg, P., Koellner, T., 2014. A Bayesian network approach to model farmers' crop choice using socio-psychological measurements of expected benefits from ecosystem services. Environmental Modelling \& Software 57, 227-234.

Power, A.G., 2010. Ecosystem services and agriculture: Tradeoffs and synergies. Philosophical Transactions of the Royal Society B: Biological Sciences 365, 2959-2971.

Raudsepp-Hearne, C., Peterson, G.D., Bennett, E.M., 2010. Ecosystem service bundles for analyzing tradeoffs in diverse landscapes. PNAS 107, 5242-5247.

Reinhard, S., Lovell, C.A.K., Thijssen, G., 2002. Analysis of environmental efficiency variation. American Journal of Agricultural Economics 84, 1054-1065.

Reinhard, S., Lovell, C.A.K., Thijssen, G.J., 1999. Econometric estimation of technical and environmental efficiency: an application to Dutch dairy farms. American Journal of Agricultural Economics 81, 44-60.

Reinhard, S., Lovell, C.A.K., Thijssen, G.J., 2000. Environmental efficiency with multiple environmentally detrimental variables: estimated with SFA and DEA. European Journal of Operational Research 121, 287-303.

Reinhard, S., Thijssen, G., 2000. Nitrogen efficiency of dutch dairy farms: A shadow cost system approach. European Review of Agricultural Economics 27, 167-186.

Ricketts, T.H., Daily, G.C., Ehrlich, P.R., Michener, C., 2004. Economic value of tropical forest to coffee production. PNAS 101, 12579-12582.

Robbins, L., 1932. An essay on the nature and significance of economic science. Macmillan, London.

Rodríguez, J. P., Beard, T.D., Bennett, E.M., Cumming, G.S., Cork, S., Agard, J., Dobson, A.P., Peterson, G.D., 2006. Trade-offs across space, time, and ecosystem services. Ecology and Society 11, 28. Rojas, M., Aylward, B., 2002. The case of La Esperanza: a small, private, hydropower producer and a conservation NGO in Costa Rica. Land-water linkages in rural watersheds case study series. FAO. Rome.

Rosenzweig, C., Elliott, J., Deryng, D., Ruane, A.C., Müller, C., Arneth, A., Boote, K.J., Folberth, C., Glotter, M., Khabarov, N., Neumann, K., Piontek, F., Pugh, T.A.M., Schmid, E., Stehfest, E., Yang, H., Jones, J.W., 2014. Assessing agricultural risks of climate change in the 21st century in a global gridded crop model intercomparison. PNAS 111, 3268-3273.

Ruidisch, M., Nguyen, T.T., Li, Y.L., Geyer, R., Tenhunen, J., 2014. Estimation of annual spatial variations in forest production and crop yields at landscape scale in temperate climate regions. Ecological Research, doi:10.1007/s11284-014-1208-4.

Scarlett, L., Boyd, J., 2013. Ecosystem services and resource management: institutional issues, challenges, and opportunities in the public sector. Ecological Economics, doi:10.1016/j.ecolecon.2013.09.013. 


\section{Introduction}

Scholz, R.W., Binder, C.R., 2003. The paradigm of human-environment systems. Working Paper No. 37. Natural and Social Interface, ETH Zürich.

Scholz, V., Ellerbrock, R., 2002. The growth productivity and environmental impact of the cultivation of energy crops on sandy soil in Germany. Biomass and Bioenergy 23, 81-92.

Schulze, E.D., 1989. Air pollution and forest decline in a spruce (Piceaabies) forest. Science 244, 776-783.

Seidl, R., Rammer, W., Jager, D., Currie, W.S., Lexer, M.J., 2007. Assessing trade-offs between carbon sequestration and timber production within a framework of multi-purpose forestry in Austria. Forest Ecology and Management 248, 64-79.

Seppelt, R., Fath, B., Burkhard, B., Fisher, J.L., Gret-Regamey, A., Lautenbach, S., Pert, P., Hotes, S., Spangenberg, J., Verburg, P.H., van Oudenhoven, A.P.E., 2011. Form follows function? Proposing a blueprint for ecosystem service assessments based on reviews and case studies. Ecological Indicators 21, 145-154.

Seppelt, R., Müller, F., Schröder, B., Volk, M., 2009. Challenges of simulating complex environmental systems at the landscape scale: A controversial dialogue between two cups of espresso. Ecological Modelling 220, 3481-3489.

Seppelt, R.,Richter, O., 2005. It was an artefact not the results - A note on system dynamic model development. Environmental Modelling \& Software 20, 1543-1548.

Seppelt, R.,Voinov, A., 2003. Optimization methodology for land use patterns: Evaluation based on multiscale habitat pattern comparison. Ecological Modelling 168, 217-231.

Shaik, S., Helmers, G.A., Langemeier, M.R., 2002. Direct and indirect shadow price and cost estimates of nitrogen pollution abatement. Journal of Agricultural and Resource Economics 27, 420-432.

Singh, S.J., Haberl, H., Schmid, M., Mirtl, M., Chertow, M., 2013. Long-term socio-ecological research: Studies in society-nature interactions across spatial and temporal scales. Springer, Dordrecht.

Skevas, T., Oude Lansink, A., Stefanou, S.E., 2012. Measuring technical efficiency in the presence of pesticide spillovers and production uncertainty: the case of Dutch arable farms. European Journal of Operational Research 223, 550-559.

Stapleton, L.M., Hanna, P., Ravenscroft, N., Church, A., 2014. A flexible ecosystem services prototypology based on public opinion. Ecological Economics 106, 83-90.

Steffan-Dewenter, I., Kessler, M., Barkmann, J., Bos, M.M., Buchori, D., Erasmi, S., Faust, H., Gerold, G., Glenk, K., Gradstein, S.R., Guhardja, E., Harteveld, M., Hertel, D., Höhn, P., Kappas, M., Köhler, S., Leuschner, C., Maertens, M., Marggraf, R., Migge-Kleian, S., Mogea, J., Pitopang, R., Schaefer, M., Schwarze, S., Sporn, S.G., Steingrebe, A., Tjitrosoemito, S., Twele, A., Weber, R., Woltmann, L., Zeller, M., Tscharntke, T., 2007. Tradeoffs between income, biodiversity, and ecosystem functioning during tropical rainforest conversion and agroforestry intensification. PNAS 104, 4973-4978. 


\section{Introduction}

Stern, N., 2007. Stern Review: The economics of climate change. Cambridge University Press, Cambridge.

Swallow, B.M., Sang, J.K., Nyabenge, M., Bundotich, D.K., Duraiappah, A.K., Yatich, T.B., 2009. Tradeoffs, synergies and traps among ecosystem services in the Lake Victoria Basin of East Africa. Environmental Science \& Policy 12, 504-519.

Swinton, S.M., Lupi, F., Robertson, G.P., Hamilton, S., K., 2007. Ecosystem services and agriculture: Cultivating agricultural ecosystems for diverse benefits. Ecological Economics 64, 245-252.

Tallis, H., Kareiva, P., 2005. Ecosystem services. Current Biology 15, 746-748.

Tallis, H., Kareiva, P., Marvier, M., Chang, A. 2008. An ecosystem services framework to support both practical conservation and economic development. PNAS 105, 9457-9646.

Tancoigne, E., Barbier, M., Cointet, J-P., Richard, G., 2014.The place of agricultural sciences in the literature on ecosystem services. Ecosystem Services 10, 35-48.

TEEB, 2010. The ecological and economic foundation. Available at http://www.teebweb.org

Tenhunen, J., Nguyen, T.T., Choi, I.C., Park, J.Y., Kim, S.J., Shin, H.J. 2015. Analyzing time dependent change in ecosystem service provision in a regional social-ecological-system: a watershed-oriented approach.Unpublished, University of Bayreuth.

Therrien, R., McLaren, R., Sudicky, E., Panday, S., 2010. HydroGeoSphere: a three dimensional numerical model describing fully integrated subsurface and surface flow and solute transport (draft). Groundwater Simulations Group. Waterloo.

Tilman, D., Cassman, K.G., Matson, P.A., Naylor, R., Polasky, S., 2002. Agricultural sustainability and intensive production practices. Nature 418, 671-677.

Tol, R.S.J., 2010. Economics of Climate Change. Perspektiven der Wirtschaftspolitik 11, 13-17.

Turner, R.K., Daily, G.C., 2008. The ecosystem services framework and natural capital conservation. Environmental and Resource Economics 39, pp. 25-35.

Turton, C., 2000. The sustainable livelihoods approach and programme development in Cambodia. Working Paper 130. Overseas Development Institute. London.

Tuvendal, M., Elmqvist, T., 2011. Ecosystem services linking social and ecological systems: river brownification and the response of downstream stakeholders. Ecology and Society 16, 21.

Tyteca, D., 1999. Sustainability indicators at the firm level. Journal of Industrial Ecology 2, 61-77.

Ulbrich, K., Drechsler, M., Wätzold, F., Johst, K., Settele, J., 2008. A software tool for designing costeffective compensation payments for conservation measures. Environmental Modelling \& Software 23, $122-123$

Van Jaarsveld, A.S., Biggs, R., Scholes, R.J., Bohensky, E., Reyers, B., Lynam, T., Musvoto, C., Fabri- 


\section{Introduction}

cius, C., 2005. Measuring conditions and trends in ecosystem services at multiple scales: The Southern African Millennium Ecosystem Assessment (SAfMA) experience. Philosophical Transactions of the Royal Society B: Biological Sciences 360, 425-441.

Van Meensel, J., Lauwers, L., Van Huylenbroeck, G., Van Passel, S., 2010. Comparing frontier methods for economic-environmental trade-off analysis. European Journal of Operational Research 207, 10271040.

Verutes, G.M., Rosenthal, A., 2014. Using simulation games to teach ecosystem service synergies and trade-offs. Environmental Practice 16, 194-204.

Viglizzo, E.F., Frank, F.C., 2006. Ecological interactions, feedbacks, thresholds and collapses in the Argentine Pampas in response to climate and farming during the last century. Quaternary International $158,122-126$.

Vignola, R., Koellner, T., Scholz, R., McDaniels, T., 2010. Decision making by farmers regarding ecosystem services: factors affecting soil conservation efforts in Costa Rica. Land Use Policy 27, 11321142.

Vitousek, P. M., Aber, J. D., Howarth, R.W., Likens, G.E., Matson, P.A., Schindler, D.W., Schlesinger, W.H., Tilman, D.G., 1997. Human alteration of the global nitrogen cycle: sources and consequences. Ecological Applications 7, 737-750.

Volk, M., 2013. Modelling ecosystem services: Challenges and promising future directions. Sustainability of Water Quality and Ecology 1, 3-9.

von Lampe, M., 2007. Economics and agricultural market impacts of growing biofuel production. Agrarwirtschaft 56, 232-237.

Walker, B., Carpenter, S., Anderies, J., Abel, N., Cumming, G.S., Janssen, M., Lebel, L., Norberg, J., Peterson, G.D., Pritchard, R. 2002. Resilience management in social-ecological systems: a working hypothesis for a participatory approach. Conservation Ecology 6, 14.

Wallace, K.J., 2007. Classification of ecosystem services: Problems and solutions. Biological Conservation 139, 235-246.

Wang, S., Fu, B., 2013. Trade-offs between forest ecosystem services. Forest Policy and Economics 26, 145-146.

Wätzold, F., Drechsler, M., Armstrong, C.W., Baumgärtner, S., Grimm, V., Huth, A., Perrings, C., Possingham, H.P., Shogren, J.F., Skonhoft, A., Verboom-Vasiljev, J., Wissel, C., 2006. Ecologicaleconomic modeling for biodiversity management: Potential, pitfalls, prospects. Conservation Biology 20, 1034-1041.

WCED (World Commission on Environment and Development), 1987. Our common future. Oxford University Press, Oxford. 


\section{Introduction}

Wegner, G., Pascual, U., 2011. Cost-benefit analysis in the context of ecosystem services for human well-being: A multidisciplinary critique. Global Environmental Change 21, 492-504.

Wei, Y.P., Davidson, B., Chen, D., White, R., 2009. Balancing the economic, social and environmental dimensions of agro-ecosystems: an integrated modelling approach. Agriculture, Ecosystems \& Environment 131, 263-273.

Westman, W., 1977. How much are nature's services worth. Science 197, 960-964.

White, C., Halpern, B.S., Kappel, C.V., 2012. Ecosystem service tradeoff analysis reveals the value of marine spatial planning for multiple ocean uses. PNAS 109, 4696-4701.

Williamson, O.E., 1975. Markets and hierarchies: Analysis and antitrust implications: A study in the economics of internal organization. Free Press.

Winthrop, R.H., 2014. The strange case of cultural services: Limits of the ecosystem services paradigm. Ecological Economics 108, 208-214.

Wissel, S., Wätzold, F., 2010. A conceptual analysis of the application of tradable permits to biodiversity conservation. Conservation Biology 24, 404-411.

Wunder, S., 2005. Payments for environmental services: Some nuts and bolts. CIFOR, Occasional paper No.42, Bogor.

Wunder, S., 2007. The efficiency of payments for environmental services in tropical conservation. Conservation Biology 21, 48-58.

Wunder, S., Engel, S., Pagiola, S., 2008. Taking stock: A comparative analysis of payments for environmental services programs in developed and developing countries. Ecological Economics 65, 834-52.

Wunder, S., The, B.D., Ibarra, E., 2005. Payment is good, control is better: why payments for environmental services so far have remained incipient in Vietnam. CIFOR, Bogor.

Würtenberger, L., Koellner, T., Binder, C.R., 2006. Virtual land use and agricultural trade: Estimating environmental and socio-economic impacts. Ecological Economics 57, 679-697.

Zander, K.K., Garnett, S.T., 2011. The economic value of environmental services on indigenous-held lands in Australia. PLoS ONE 6, e23154, doi.org/10.1371/journal.pone.0023154.

Zhou P., Ang B.W., Poh, K.L., 2008. A survey of data envelopment analysis in energy and environmental studies. European Journal of Operational Research 189, 1-18. 